\title{
Current Antivirals and Novel Botanical Molecules Interfering With Herpes Simplex Virus Infection
}

\author{
Diana M. Álvarez ${ }^{1}$, Estefanía Castillo', Luisa F. Duarte', José Arriagada', \\ Nicolás Corrales ${ }^{1}$, Mónica A. Farias ${ }^{1}$, Adolfo Henríquez ${ }^{2}$, Cristian Agurto-Muñoz ${ }^{2,3}$ and \\ Pablo A. González ${ }^{*}$

\begin{abstract}
${ }^{1}$ Millennium Institute on Immunology and Immunotherapy, Departamento de Genética Molecular y Microbiología, Facultad de Ciencias Biológicas, Pontificia Universidad Católica de Chile, Santiago, Chile, ${ }^{2}$ Centro de Biotecnología, Universidad de Concepción, Concepción, Chile, ${ }^{3}$ Departamento de Ciencia y Tecnología de Alimentos, Facultad de Farmacia,

Universidad de Concepción, Concepción, Chile
\end{abstract}

OPEN ACCESS

Edited by:

Michael Nevels,

University of St Andrews,

United Kingdom

Reviewed by:

David Leib,

Dartmouth College, United States

Guangdi Li,

Central South University, China

*Correspondence:

Pablo A. González pagonzalez@bio.puc.cl

Specialty section:

This article was submitted to

Virology,

a section of the journa

Frontiers in Microbiology

Received: 28 October 2019

Accepted: 21 January 2020

Published: 11 February 2020

Citation:

Álvarez DM, Castillo E, Duarte LF, Arriagada J, Corrales N, Farías MA,

Henríquez A, Agurto-Muñoz $C$ and González PA (2020) Current Antivirals and Novel Botanical Molecules Interfering With Herpes Simplex Virus Infection. Front. Microbiol. 11:139. doi: 10.3389/fmicb.2020.00139
Herpes simplex viruses type 1 (HSV-1) and type 2 (HSV-2) are highly prevalent within the human population and are characterized by lifelong infections and sporadic recurrences due to latent neuron infection. Upon reactivations, HSVs may manifest either, symptomatically or asymptomatically and be shed onto others through mucosae body fluids. Although, HSVs can produce severe disease in humans, such as lifethreatening encephalitis and blindness, the most common symptoms are skin and mucosal lesions in the oro-facial and the genital areas. Nucleoside analogs with antiviral activity can prevent severe HSV infection, yet they are not very effective for treating skin manifestations produced by these viruses, as they only reduce in a few days at most the duration of lesions. Additionally, HSV variants that are resistant to these antivirals may arise, especially in immunosuppressed individuals. Thus, new antivirals that can reduce the severity and duration of these cutaneous manifestations would certainly be welcome. Here, we review currently available anti-herpetic therapies, novel molecules being assessed in clinical trials and new botanical compounds reported in the last 20 years with antiviral activities against HSVs that might represent future treatments against these viruses.

Keywords: HSV-1, HSV-2, natural antiviral compounds, antiviral extracts, phytopharmaceuticals, therapy

\section{INTRODUCTION}

Herpes simplex virus type 1 (HSV-1) and herpes simplex virus type 2 virus (HSV-2) are viruses belonging to the Herpesviridae family, Alphaherpesvirinae subfamily and Simplexvirus genus. HSV-1 and HSV-2 belong to the same family and subfamily than varicella zoster virus (VZV), yet VZV belongs to the Varicellovirus genus (McGeoch, 2009; Kinchington et al., 2012; Ibáñez et al., 2018). HSV-1 and HSV-2 are highly prevalent in humans, with global infections ranging 70 and $10 \%$ of the world population, respectively (Smith and Robinson, 2002; Schillinger et al., 2004; Looker et al., 2008; Chayavichitsilp et al., 2009; Doi et al., 2009) (World Health Organization, Regional Estimates ${ }^{1}$.

\footnotetext{
${ }^{1}$ http://www.who.int/mediacentre/news/releases/2015/herpes/en/
} 
HSV-1 and HSV-2 can cause severe disease in immunocompetent adults and newborns, such as life-threatening encephalitis with sequelae, despite antiviral treatment (Whitley et al., 2007; Xu et al., 2007; Dinh et al., 2008; Handel et al., 2011). These viruses can also produce eye infections leading to visual impairment: currently, HSV-1 is the main cause of infectious blindness in developed countries (Farooq and Shukla, 2012). However, the most common clinical manifestations associated to HSV-1 and HSV-2 infections are herpes labialis and herpes genitalis (Lafferty et al., 1987; Mertz et al., 1998; Kaye and Choudhary, 2006; Paz-Bailey et al., 2008; Farooq and Shukla, 2012), which are characterized by the appearance of vesicular ulcers in the oro-facial and genital areas that gradually dry out into crusts and may last up to 14 days during primary infections and approximately 10 days during recurrences if no treatment is undertaken (Arduino and Porter, 2007). Lesion development is sequential and begins with a prodrome displaying erythema, then papules emerge which may progress into vesicles that break up giving way to the formation of ulcers. Finally, these ulcers dry out forming scabs, which are accompanied by residual swelling and finally healing (Spruance et al., 1977; Corey et al., 1983; Fatahzadeh and Schwartz, 2007). The lesions contain high amounts of virions and infiltrating leukocytes and may be painful with a burning sensation, ultimately impacting the quality of life of the affected individuals (Spruance et al., 1977; Dreno et al., 2012).

Nevertheless, not all the individuals infected with HSV-1 and HSV-2 manifest symptoms. It is estimated that herpetic recurrences due to $\mathrm{HSV}$ occur within a wide range of frequencies, varying between $20-50 \%$ and $80-90 \%$ for HSV-1 and HSV-2 infections, respectively after primary infection (Mertz et al., 1992; Benedetti et al., 1994; Cowan et al., 1994; Fleming et al., 1997). This means that $50-80 \%$ and $10-20 \%$ of individuals with HSV1 and HSV-2 infection, correspondingly will not show clinical symptoms of infection. Yet, it is important to note that these persons will nevertheless shed infectious viral particles from the mucosae, which could infect other individuals (Johnston and Corey, 2015; Ramchandani et al., 2017). On the other hand, up to one-third of the persons that have had clinical symptoms during primary infection show frequent reactivations, which occur on average six times a year (Benedetti et al., 1994). Overall, it is currently estimated that $10-25 \%$ of the individuals that are infected with HSV manifest disease symptoms, particularly skin lesions in various forms (herpes labialis, herpes genitalis, eczema herpeticum, zosteriforme herpes, etc.) (Mertz et al., 1992; Cowan et al., 1994; Fleming et al., 1997). Taking into consideration the numbers outlined above, approximately 16 and $5 \%$ of the world population will manifest herpetic lesions with HSV-1 and HSV-2, respectively. This extremely high percentage of individuals affected by symptomatic HSV infection is nonnegligible and undoubtedly encompasses a significant number of persons that would like to have access to more effective solutions against these viruses.

The reactivation of HSV-1 and HSV-2 from infected individuals is associated with numerous factors, such as immunerelated and physicochemical stimuli, such as UV radiation, as well as menstruation, stress and traumatic events, among others
(Perna et al., 1987; Rand et al., 1990). Upon viral reactivation, virions travel in a retrograde manner from the cell body of infected neurons in the trigeminal ganglia (orofacial infection), or the dorsal root ganglia (genital-associated infection), to sites neighboring epithelial cells and fibroblasts, nearby the original site of infection, forming new lesions that will repeat the process of additional neuron infection (Stevens and Cook, 1971; Lafferty et al., 1987; Benedetti et al., 1994). Given this scenario, it seems important to block neuron infection by HSV-1 and HSV-2 during primary infection or to treat neurons in such a way that these viruses do not reactivate from these cells. However, a prophylactic approach for HSV-1 and HSV-2 is yet not available in the form of a vaccine (Kwant and Rosenthal, 2004; Belshe et al., 2012) and the effective eradication of these viruses from neurons requires further research (van Diemen et al., 2016; van Diemen and Lebbink, 2017; Chen et al., 2018).

At present, there are several commercially available antivirals to treat skin lesions caused by HSV-1 and HSV-2. However, such drugs are somewhat ineffective for this type of clinical manifestation, as they only shorten the recovery time of the lesions in 1-2 days in most cases (Evans et al., 2000; Leflore et al., 2000). For some individuals, the effectiveness of these treatments may be imperceptible [meta-analysis: Chen et al. (2016)].

On the other hand, approximately $3.5-10 \%$ of immunosuppressed individuals (e.g., transplanted persons, HIV-positive individuals, those undergoing pharmacological treatments to depress the immune system, among others) may develop HSV-1 and HSV-2 variants that are resistant to the most commonly used antivirals (Stranska et al., 2005; Ziyaeyan et al., 2007; Suazo et al., 2014; Lolis et al., 2016). Although second line antivirals exist for these drug-resistant isolates, such as for acyclovir-resistant variants, unfortunately most of these compounds elicit numerous adverse effects (discussed below) (Javaly et al., 1999). In immunocompetent individuals, drug-resistant variants such as acyclovir-resistant isolates may also occur, yet at a lower frequency (approximately 1\% of cases) (Bacon et al., 2002; Stranska et al., 2005; Ziyaeyan et al., 2007). Although this number seems small, considering the significant number of individuals infected with HSV-1 and HSV-2, the figure is substantial.

Several natural products have shown antiviral effects against HSV-1 and HSV-2, such as extracts, fractionated compounds and isolated molecules originated from marine organisms, microorganisms, fungi, animals, algae and plants, among others (Hassan et al., 2015). Among these bioactive products there are marine-derived nucleosides, such as spongothymidine and spongouridin, which gave origin to the first nucleoside analog drugs approved to control HSV-1 and HSV-2 infection (Hassan et al., 2015). Additionally, many plants used in herbal medicine have been reported worldwide to have antiviral effects against HSV-1 and HSV-2 (Lipipun et al., 2003; Jadhav et al., 2012; Brand et al., 2016; Li et al., 2018). Interestingly, different types of natural compounds display antiherpetic activity, such as alkaloids (Souza et al., 2007), polysaccharides (Damonte et al., 2009) and proteins (Gu et al., 2007).

Here, we review and discuss current antivirals used against HSV-1 and HSV-2, novel antiviral molecules tested in clinical 
trials against these viruses, as well as new compounds of botanical origin that have emerged in the last 20 years to treat herpes simplex viruses.

\section{CURRENT DRUGS USED AGAINST HSV-1 AND HSV-2}

At present, there are numerous antiviral drugs for the treatment of HSV infections. Some commonly known anti-herpetic drugs that are currently being used include acyclovir (ACV), penciclovir, and famciclovir, which inhibit HSV-1 and HSV2 infection by interfering with the viral DNA polymerase and hence, viral genome replication (Kukhanova et al., 2014). These drugs are also used to treat other herpesvirus infections, such as VZV and cytomegalovirus (human herpesvirus 5, HHV-5, CMV). Although several of these drugs, which are described in more detail below, help reduce disease and minimize potential severe damage, as well as to limit the spread of these viruses onto other individuals, most of these compounds only modestly reduce cutaneous manifestations (lesions) caused by herpes simplex viruses, particularly when used in the form of creams that are applied topically to the skin (Lebrun-Vignes et al., 2007; Hammer et al., 2018).

\section{Acyclovir}

Numerous antivirals approved for the treatment of HSV-1 and HSV-2 infections are acyclic nucleoside and nucleotide analogs that interfere with the elongation of viral genome during replication, which is carried out by the viral DNA polymerase (UL30). Acyclovir (ACV) is an acyclic guanosine analog discovered in the sponge Cryptotethya crypta and is at present the most frequently used compound to treat HSV-1 and HSV-2, mainly because of its low price, tolerability and safety (Hassan et al., 2015). Importantly, acyclovir needs to be activated intracellularly by its phosphorylation into acyclovir triphosphate for exerting its antiviral activity. This process is carried out by the viral thymidine kinase (TK, UL23 gene), which catalyzes acyclovir into acyclovir monophosphate, thus increasing the concentration of acyclovir within infected cells by reducing its exit from the cell (Reusser, 1996; Kukhanova et al., 2014). Additional phosphorylations are carried out by cellular kinases and once in its triphosphate form, acyclovir becomes a substrate for the viral DNA polymerase interfering with DNA synthesis (Reusser, 1996; De Clercq, 2013). Importantly, inhibition of the synthesis of new viral genome copies, which translates lesser formation of novel infectious viral particles, does not affect latent virus within host neurons and hence, does not cure infection (Poole and James, 2018). Other limitations related to the treatment with ACV also exist. For instance, oral intake of ACV has an absorption efficiency of only 15-30\% (Bean, 1992), and previous reports indicated that senior patients that had renal problems could experience significant neurotoxicity, because they were not able to properly excrete this drug (Chau, 2018). Another important limitation associated to ACV is the ability of HSV-1 and HSV-2 to mutate and generate variants that are resistant to this drug by acquiring point mutations in the gene encoding for the viral thymidine kinase (TK), which decreases enzyme expression or modifies substrate specificity abrogating acyclovir phosphorylation, or by acquiring mutations in the gene encoding for the viral DNA polymerase (UL30), which may enable HSV-1 and HSV-2 to replicate in the presence of ACV (Reusser, 1996). Such ACV-resistant variants occur mainly in immunosuppressed individuals, as they are otherwise generally attenuated in immunocompetent individuals (Field, 2001; Morfin and Thouvenot, 2003).

Oral intake of ACV for treating skin lesions produced by HSV-1 and HSV-2 only reduces the healing process in little more than 2 days (time to loss of scab), from 7.9 days (placebo group) to 5.8 days, if taken as soon as signs of the prodrome or erythema are detected (Spruance et al., 1990). Because these differences are moderate, although statistically significant, the clinical benefit of these antiviral drugs for the treatment of herpetic lesions has been somewhat questioned (Kroon, 1990; Mindel, 1991). Importantly, when the drug is taken at the stage of papule, a significant effect for ACV is not observed (Spruance, 1993). Furthermore, within this scenario, the recovery time of cutaneous lesions was found to be larger in the treated group (antiviral) than in the placebo group ( 8 days vs. 7.2 days, respectively). Regretfully, nearly $50 \%$ of patients fail to perceive initial stages of the prodrome and the erythema phases before papule formation and therefore these individuals will not be in time to start an effective oral treatment with ACV in such a way to significantly reduce the time of the herpetic lesions (Spruance et al., 1990; Spruance, 1993). Thus, treatment with ACV has poor benefits under these circumstances (Spruance et al., 1990).

As an alternative to oral intake, ACV can be applied topically as a cream. Although topical application of ACV over herpetic lesions at the papule stage has beneficial effects, these benefits are relatively weak, since they only reduce healing time in approximately one or two days during herpes labialis (Bean, 1992; Evans et al., 2000) and three days in genital herpes infections (Thin et al., 1983; Leflore et al., 2000).

\section{Valacyclovir, Penciclovir, and Famciclovir}

Besides ACV, there are other alternatives to treat skin lesions caused by herpes simplex viruses, such as valacyclovir, penciclovir, and famciclovir, which are also considered first-line drugs to treat HSV-1 and HSV-2 and thus, are frequently used (Kimberlin and Whitley, 2007).

These drugs are nucleic acid analogs, similar to ACV with a shared mechanism of action that interferes with the function of the viral DNA polymerase (De Clercq, 2013). These compounds differ from each other mainly in their bioavailability, half-life in the body and dosing (Wagstaff and Bryson, 1994), yet similar to $\mathrm{ACV}$ they reduce herpetic lesions and associated pain in approximately 1-3 days, as compared to untreated groups when used topically (Emmert, 2000).

To increase the bioavailability of acyclovir, an L-valine ester of acyclovir was developed. Valacyclovir is a prodrug of ACV with enhanced absorption at the intestinal level (54\%) (Soul-Lawton et al., 1995). Later, penciclovir was developed with the aim of being phosphorylated more rapidly than ACV, and consequently has a higher half-life than acyclovir (Hodge and Perkins, 1989). 
While acyclovir has a half-life of $0.7 \mathrm{~h}$ for HSV-1 and $1 \mathrm{~h}$ for HSV-2, penciclovir has a half-life of $10 \mathrm{~h}$ for HSV-1 and $20 \mathrm{~h}$ for HSV-2 (Luber and Flaherty, 1996). Famciclovir is a prodrug that derives into penciclovir and has increased oral bioavailability (Hodge et al., 1989). Clinical benefits granted by these drugs have also generated discussions on the recommendation of their use to treat skin lesions caused by herpes simplex virus infections (Chi et al., 2015; Chen et al., 2016).

Valacyclovir has also been approved for the treatment of HSV-1 and HSV-2 infections and clinical manifestations produced by HSV-1 and HSV-2, such as cold sores and recurrent genital herpes, as well as VZV and cytomegalovirus (Ormrod et al., 2000). Furthermore, famciclovir is approved for treating herpes viruses, such as HSV-1 and HSV-2 (genital herpes and orolabial herpes), as well as VZV (Simpson and Lyseng-Williamson, 2006).

Resistance to valacyclovir, penciclovir, and famciclovir can occur. Furthermore, there is cross-resistance between valacyclovir- and acyclovir-resistant HSV isolates (Reusser, 1996), because valacyclovir is derived from acyclovir (Moomaw et al., 2003). On the other hand, cross resistance to penciclovir and the prodrug famciclovir may arise in acyclovir-resistant HSV-1 isolates in immunocompromised patients (Boyd et al., 1993). Some studies have reported HSV-1 and HSV-2 resistance to penciclovir in cell cultures and in immunocompromised patients related to TKdeficiency (Boyd et al., 1993; Sarisky et al., 2002, 2003; Bacon et al., 2003).

\section{Ganciclovir, Cidofovir and Foscarnet}

In the last decade, alternatives to ACV for herpesvirus treatment have emerged and become commercially available as therapeutic drugs. Ganciclovir is a nucleic acid analog that does not require viral proteins for its activation in the cell (i.e., viral TK) (Markham and Faulds, 1994; Prichard et al., 2011; Vere Hodge and Field, 2013; Poole and James, 2018). These compounds differ from each other either, in their molecular processing into an active form of an acyclic guanosine analog, or bioavailability which significantly determines the frequency of administration (De Clercq, 2013).

Ganciclovir is indicated for the treatment of CMV, particularly for systemic and ocular infections in immunosuppressed patients (Buhles et al., 1988; Poole and James, 2018). However, ganciclovir has also been reported to have antiviral activity against HSV-1 and HSV-2 and may be used for the treatment of herpetic keratitis (Smee et al., 1983; Matthews and Boehme, 1988; Chou and Hong, 2014). At present, there is an ongoing clinical study that is recruiting patients for assessing the effects of oral ganciclovir, together with femtosecond laser-assisted corneal debridement in the treatment of herpes simplex virus epithelial keratitis (ClinicalTrials.gov NCT03217474). Of note, ganciclovir has been reported to produce considerable adverse side effects in a high percentage of individuals (Kimberlin and Whitley, 2007), such as nephrotoxicity, neutropenia, myelosuppression, confusion, altered mental status, anxiety, ataxia, tremors, convulsions, fever, abnormal levels of liver enzymes in serum, diarrhea, and nausea, among others (Kimberlin and Whitley, 2007).
Other alternative drugs that have emerged in the last decades as second-line drugs that are commercially available are cidofovir (an acyclic nucleotide analog) (Ashley et al., 1988; Blot et al., 2000; James and Prichard, 2014) and foscarnet (a pyrophosphate analog) (Crumpacker, 1992; Wagstaff and Bryson, 1994). When compared to each other, these two compounds affect different steps in the viral replication cycle. Cidofovir acts as a nucleotide analog and polymerase inhibitor with a high affinity for the viral DNA polymerase, with cidofovir-diphosphate having 2550 fold higher affinity for the viral DNA polymerase than the host DNA polymerase, causing thus a more effective block in the replication of viral DNA than acyclovir (Ho et al., 1991). Importantly, cidofovir has a phosphonate group that does not require an initial phosphorylation step by HSV proteins (Ho et al., 1991). Cidofovir has shown to be efficacious against acyclovir-resistant isolates of HSV-1 or HSV-2 in vitro (Chilukuri and Rosen, 2003). However, this drug has not been approved for the treatment of herpes simplex viruses in humans. Yet, a clinical study was carried out to evaluate the effectivity of topical cidofovir for refractory mucocutaneous HSV-1 and HSV2 in AIDS; However, the results of this clinical study have not been reported (ClinicalTrials.gov Identifier: NCT00002116). On the other hand, foscarnet inhibits the viral DNA polymerase of herpesviruses by binding near to the pyrophosphate binding site that is needed for polymerase activity (Crumpacker, 1992; Poole and James, 2018). In contrast to nucleoside analogs, resistance to foscarnet only occurs because of mutations in the viral DNA polymerase gene (Reusser, 1996).

Regretfully, these two drugs also produce numerous adverse effects in patients, such as nephrotoxicity, azotemia, proteinuria, crystalluria, interstitial nephritis, acute tubular necrosis, increases in the concentrations of creatinine up to 50\%, hypoand hypercalcemia, hypo- and hyper-phosphatemia, and the formation of urogenital ulcers, among others (Deray et al., 1989; Sauerbrei, 2016). Because of these effects, it is recommended that patients receiving foscarnet be monitored clinically to control abnormalities in metabolites and electrolytes that may result in the alterations indicated above.

Resistance to foscarnet has been observed in immunocompromised individuals, particularly in patients having undergone bone marrow transplants. On the other hand, there are only few studies reporting cidofovir-resistant HSV isolates. In one case, three patients with bone marrow transplants received cidofovir as a therapy, but nevertheless showed HSV-related diseases symptoms. Cidofovir resistance was confirmed in one of the three cases with the isolate showing mutations that truncated the C-terminal of the viral DNA polymerase (Wyles et al., 2005). Notably, cidofovir resistance has also been reported in children, particularly in three patients with hematopoietic stem cell transplants that received, in a prophylactic manner acyclovir and cidofovir together, because ganciclovir produced adverse effects. Unfortunately, these children showed HSV-related stomatitis during cidofovir treatment and the authors suggested that the treatment with cidofovir did not prevent HSV-1 reactivation in the patients (Dvorak et al., 2009). Nevertheless, cidofovir is considered a good option when encountering HSV isolates that express reduced amounts of enzymes that are related to the 
phosphorylation of nucleoside analogs, or resistance to foscarnet (Reusser, 1996). For example, Blot et al. (2000) reported a clinical case of a child affected by a variant of HSV-1 resistant to ACV and foscarnet (in vitro), in which case the treatment with cidofovir was effective against this drug-resistant HSV-1. Another study reporting an HSV-1 isolate resistant to both, $\mathrm{ACV}$ and foscarnet in a girl with lymphatic leukemia indicated that only cidofovir treatment was successful at helping avoid recurrent oral stomatitis (Bryant et al., 2001).

Due to the somewhat reduced clinical benefits of the drugs mentioned above in the treatment of skin lesions caused by herpes simplex viruses, new therapeutic alternatives have emerged in the most recent years. One of these alternatives is a combination of acyclovir and hydrocortisone for topical use (Xerese $^{\circledR}$, Medivir). This formulation reduces the duration of herpetic lesions by 1.6 days (compared to 1.0 days by acyclovir when applied alone as a topic in that study) and reduces the size of the lesion area by $50 \%$ (Strand et al., 2012). While this approach yields a statistically significant improvement in the treatment of herpetic lesions, it still evidences the need for identifying new drugs or drug combinations that have even better effectiveness.

Another relatively new drug to treat skin lesions caused by HSV-1 is docosanol $10 \%$ formulated as a topical cream (Abreva ${ }^{\circledR}$, Avanir), which is the only FDA approved formulation available over the counter (OTC) to treat HSV-1 symptoms. This drug consists of an aliphatic chain (hydrophobic linear chain) with an alcohol group at one of its ends and has emulsifying properties, which is why it has been used in both, the cosmetic and food industries. Currently, docosanol $10 \%$ cream is approved for the treatment of HSV-1 lesions. However, the literature available on its effectiveness is somewhat scarce and more studies seem to be required to compare its effectiveness side by side with other compounds such as acyclovir 5\% cream and Xerese ${ }^{\circledR}$ (Woo and Challacombe, 2007). One study indicates that docosanol $10 \%$ cream reduces the healing time of oral lesions due to HSV-1 and HSV-2 by $18 \mathrm{~h}$ (Sacks et al., 2001). The mechanism of action of docosanol would be mediated by the inhibition of the fusion of the virus to the cell membrane (Pope et al., 1998).

On the other hand, another drug marketed to treat skin lesions due to HSV-2 infection is Viroxyn ${ }^{\circledR}$ (Quadex Pharmaceuticals), which consists of benzalkonium chloride, a Category III antiseptic, that is also used for various applications, mainly as a biocidal preservative. This compound would act as a virucidal agent over herpes simplex viruses (Bélec et al., 2000). Although Viroxyn has been sold for more than 16 years, there are only limited studies that have evaluated its effectiveness, some proposing that it is more effective than Abreva ${ }^{\circledR}$ (McCarthy et al., 2012). However, in 2016 the FDA announced a ban on the sale of numerous bactericidal ingredients, leaving benzalkonium chloride in a "stand-by" status until obtaining clinical results that prove its safety in humans, so it may eventually be recalled ("Safety and Effectiveness of Consumer Antiseptics; Topical Antimicrobial Drug Products for Over-the-Counter Human Use.” 2016-09-06. Retrieved October 05, 2016) (Wolf, 2017).

Finally, another compound marketed for treating skin lesions caused by HSV-1 is Novitra ${ }^{\circledR}$, which consists of a zinc oxide-based cream. This compound has been shown to reduce HSV-1 skin lesions by up to 1.5 days, compared to untreated individuals (Godfrey et al., 2001). Other aspects, such as pain formation and itching, were also shown to be improved with its use. Table 1 summarizes the antiviral compounds discussed above.

\section{Other Anti-HSV Compounds}

Other anti-HSV compounds, are the nucleoside analogs idoxuridine and vidarabine, which are currently discontinued as there are at present better and more effective treatments available. Trifluridine, which is also a nucleoside analogs is mainly used to treat herpetic keratitis.

Idoxuridine is a thymidine (pyrimidine) analog that was identified as the first effective topical agent against HSV infection (Chou and Hong, 2014; Wilhelmus, 2015), and was mainly used topically as an ointment for treating epithelial keratitis caused by HSV-1 infection of the corneal epithelium (Roozbahani and Hammersmith, 2018). However, its efficacy was clouded by its toxicity to the corneal epithelium of the eye and poor hydrosolubility and thus, has been currently replaced in favor of more effective, better-tolerated and less-toxic compounds (Wilhelmus, 2015).

On the other hand, vidarabine is a purine analog with fewer side-effects than idoxuridine, yet it is also poorly soluble and therefore its use is limited to topical formulations, being less preferable than other current drugs available (Chou and Hong, 2014).

Trifluridine on the other hand is a synthetic pyrimidine nucleoside that is frequently used for the treatment of herpetic keratitis as a topical formulation. This drug was approved by the FDA in 1980 for its use as a 1\% solution treatment for HSV-related keratitis and is at present one of the most common used topical antiviral for this type of affection in the United States (Chou and Hong, 2014), with considerable effectivity reported (Wilhelmus, 2015). However, local side effects have been described, some particularly severe. Table 1 summarizes the antiviral activity of these compounds.

Finally, another anti-HSV agent is brivudine (BVDU), a pyrimidine analog that acts as a prodrug, phosphorylated by viral thymidine kinase only and thus targeting the viral DNA polymerase (Wilhelmus, 2015). This compound has been proven to be efficacious against HSV-1 and at least as effective as acyclovir in the treatment of HSV-1 infection (Chou and Hong, 2014). Currently, is mainly used in different countries for treatment of VZV infections (De Clercq, 2019).

\section{Compounds Against HSVs Currently Being Assessed in Clinical Trials}

Currently, several new anti-herpetic drugs are being assessed in clinical trials, such as brincidofovir (Quenelle et al., 2010; Prichard et al., 2011), amenamevir (Chono et al., 2010), pritelivir (Wald et al., 2014), and nelfinavir mesylate (Kalu et al., 2014).

Brincidofovir is an acyclic nucleotide phosphonate, similar to cidofovir, yet it is conjugated to a lipid (Jiang et al., 2016). When brincidofovir enters the cell, the lipid sidechain is cleaved and the compound is phosphorylated, acting as a 
TABLE 1 | Approved and experimental antiviral drugs against HSV-1 and HSV-2 (non-botanical).

\begin{tabular}{|c|c|c|c|c|}
\hline Drug & Mechanism of action & Type of molecule & Status & References \\
\hline Acyclovir & Inhibitor of viral DNA replication & Nucleoside analog & Approved by FDA and EMA & Gnann et al., 1983 \\
\hline Valacyclovir & Inhibitor of viral DNA replication & Nucleoside analog & Approved by FDA and EMA & Schuster et al., 2016 \\
\hline Penciclovir & Inhibitor of viral DNA replication & Nucleoside analog & Approved by FDA and EMA & Meira et al., 2019 \\
\hline Famciclovir & Inhibitor of viral DNA replication & Nucleoside analog & Approved by FDA and EMA & Mondal, 2007 \\
\hline Ganciclovir & Inhibitor of viral DNA replication & Nucleoside analog & Approved by FDA and EMA & Al-Badr and Ajarim, 2018 \\
\hline Foscarnet & Inhibitor of viral DNA replication & Pyrophosphate analog & Approved by FDA and EMA & Crumpacker, 1992 \\
\hline Cidofovir & Inhibitor of viral DNA replication & Nucleotide analog & Approved by FDA and EMA & Lea and Bryson, 1996 \\
\hline Docosanol & Viral entry inhibitor & Saturated alcohol & Approved by FDA and EMA & Treister and Woo, 2010 \\
\hline $\begin{array}{l}\text { Benzalkonium } \\
\text { chloride }\end{array}$ & Virucidal & Alkylamine & Stand-by in the United States & Taylor-Robinson and Ballard, 2001 \\
\hline Idoxuridine & Inhibitor of viral DNA replication & Deoxyuridine analog & Approved by FDA and EMA & $\begin{array}{l}\text { Chou and Hong, 2014; Wilhelmus, } \\
\text { 2015; De Clercq and Li, 2016; } \\
\text { Roozbahani and Hammersmith, } 2018\end{array}$ \\
\hline Vidarabine & Inhibitor of viral DNA replication & Nucleoside analog & Approved by FDA and EMA & Chou and Hong, 2014 \\
\hline Trifluridine & Inhibitor of viral DNA replication & Nucleoside analog & Approved by FDA and EMA & Wilhelmus, 2015 \\
\hline Brivudine & Inhibitor of viral DNA replication & Nucleoside analog & Approved by EMA & De Clercq, 2019 \\
\hline Brincidofovir & Inhibitor of viral DNA replication & Nucleotide analog & Under FDA Review & Lee et al., 2018 \\
\hline Amenamevir & Inhibitor of viral DNA replication & Helicase-Primase inhibitor & Being assessed in clinical trials & Kawashima et al., 2017 \\
\hline Pritelivir & Inhibitor of viral DNA replication & Helicase-Primase inhibitor & Being assessed in clinical trials & Wald et al., 2014 \\
\hline Nelfinavir mesylate & $\begin{array}{l}\text { Inhibits the maturation and } \\
\text { export of viral particles }\end{array}$ & HIV-1 protease inhibitor & $\begin{array}{l}\text { Being assessed in clinical trials } \\
\text { for HSV }\end{array}$ & Kalu et al., 2014 \\
\hline
\end{tabular}

substrate inhibitor for the viral DNA polymerase. Noteworthy, brincidofovir accumulates within the cell significantly more than cidofovir, and has up to 1,000-fold higher antiviral activity as compared to the latter (Hostetler, 2009). Brincidofovir was evaluated in phase III clinical trial that has concluded, yet to our knowledge the results have not been reported (ClinicalTrials.gov Identifier: NCT01143181).

On the other hand, amenamevir and pritelivir target the viral DNA helicase/primase complex (H/P) (Kleymann et al., 2002; Poole and James, 2018). There are three finished clinical studies for pritelivir, yet similar to brincidofovir, the results have not been reported to the best of our knowledge (ClinicalTrials.gov Identifier: NCT01047540, NCT01658826, and NCT02871492). There is also one clinical study that is currently ongoing and is in the recruitment phase for immunocompromised subjects with acyclovir-resistant mucocutaneous HSV-1 or HSV-2 infection (ClinicalTrials.gov Identifier: NCT03073967). Amenamevir is an oxadiazolephenyl derivate that belongs to the helicase-primase group of inhibitors and has been evaluated in at least three clinical trials, although the results have not been published (ClinicalTrials.gov Identifier: NCT02209324, NCT01959295, and NCT02852876) (Chono et al., 2010). Regretfully, a study indicates that amenamevir displayed adverse events in an early clinical phase against HSV-1 and HSV-2 (Chono et al., 2010).

Finally, nelfinavir mesylate, the mesylate salt of the antiviral drug nelfinavir which has been characterized as a HIV-1 protease inhibitor (Patick et al., 1996; Markowitz et al., 1998), was found to have antiviral activity against HSV-1 and other herpesviruses and to inhibit the maturation and export of viral particles (Kalu et al., 2014). As a consequence, nelfinavir mesylate is currently being assessed in a clinical study for the treatment of patients with Kaposi's sarcoma, as well as its potential effectivity activity against HSV-1 and HSV-2, which is a tertiary goal in this study (ClinicalTrials.gov Identifier: NCT03077451).

\section{BOTANICAL COMPOUNDS WITH ANTIVIRAL ACTIVITY AGAINST HSVs}

\section{Algae-Derived Compounds With Antiviral Activity Against HSVs in Cell Cultures}

Many studies have reported the existence of algae with bioactive compounds that display potent antiviral activity against numerous viruses, such as dengue (Lee et al., 2006; Pujol et al., 2012), avian influenza (Gerber et al., 1958), HIV (Lee et al., 1999; Thuy et al., 2015), human papillomavirus (HPV) (Buck et al., 2006), and picornavirus (Lee et al., 2009). Also, numerous studies have reported algae with antiviral activity against herpes simplex viruses (Faral-Tello et al., 2012; Ribeiro et al., 2012; Hassan et al., 2015). A study performed in Brazil analyzed more than 36 species of algae from its coasts and reported that four of them had significant antiviral activity against both, HSV-1 and HSV-2. In their study, the authors suggested that the antiviral activity of extracts of green alga Stypopodium zonale (Ochrophyta) against HSV-1 was related to the secondary metabolite atomaric acid (Figure 1) (Ribeiro et al., 2012). On the other hand, the antiviral activity of Ulva fasciata and Codium decorticatum against HSV-1 were shown to be mediated by fatty acids present in high concentrations in the extracts, yet the precise molecules involved were not identified or reported (Ribeiro et al., 2012). For the red alga Laurencia dendroidea, the antiviral activity against HSV-1 was likely mediated by sesquiterpenes (Ribeiro et al., 2012). 
A Bioactive molecules isolated from algae with antiviral activity against HSV

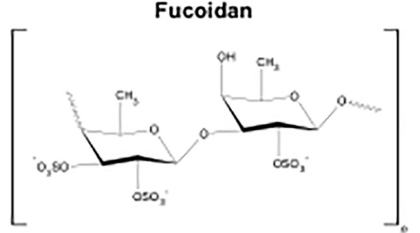

2,3,6-tribromo-4,5-dihydroxybenzy methyl ether<smiles>OCc1c(Br)cc(O)c(O)c1Br</smiles>

Atomaric acid

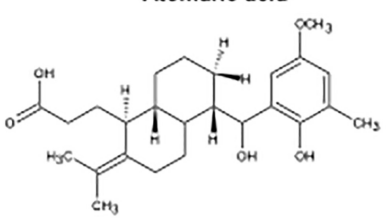

Sulfated polysaccharides

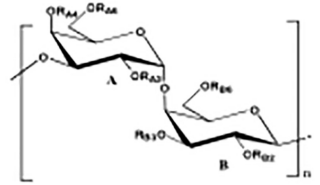

Xylan (1,4-ß-D-xylopyranosyl
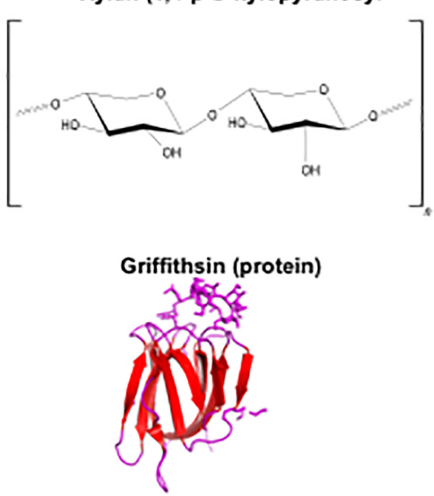

B Bioactive molecules isolated from fungi with antiviral activity against HSV

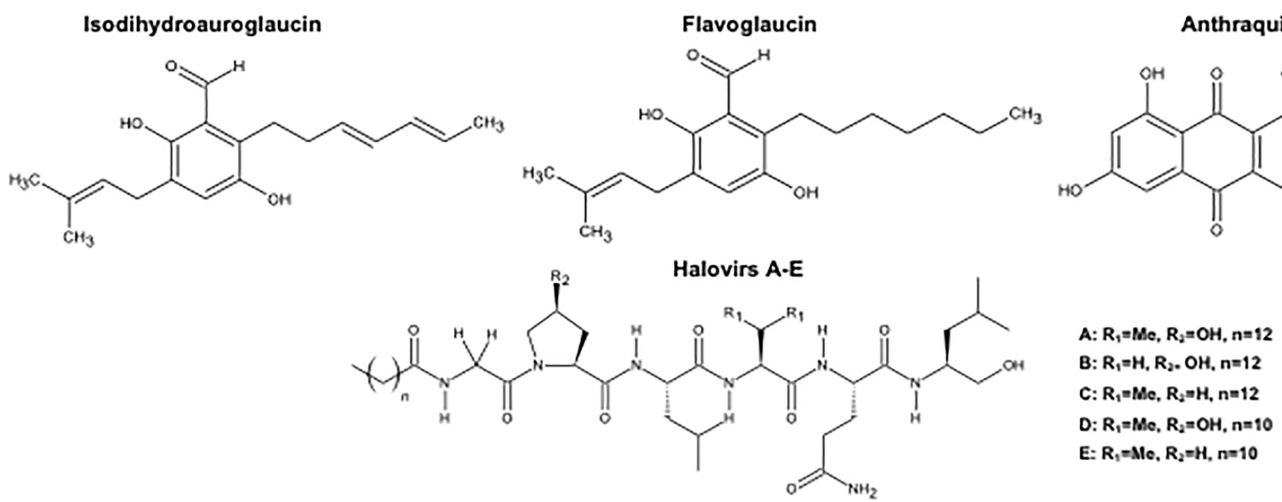

C Bioactive molecules isolated from plants with antiviral activity against HSV

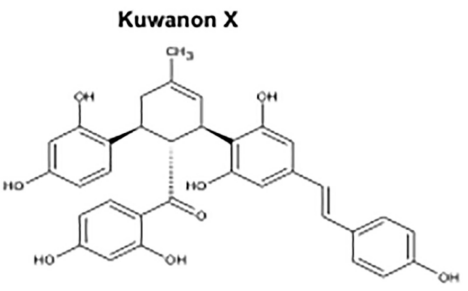

Quercetin<smiles>O=c1c(O)c(-c2ccc(O)c(O)c2)oc2cc(O)cc(O)c12</smiles>

Resveratrol

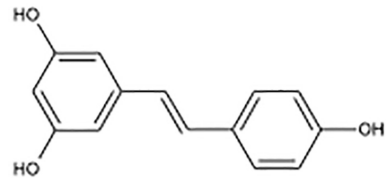

Quercitrin<smiles>C[C@@H]1O[C@H](Oc2c(-c3ccc(O)c(O)c3)oc3cc(O)cc(O)c3c2=O)[C@H](O)[C@@H](O)[C@@H]1O</smiles>

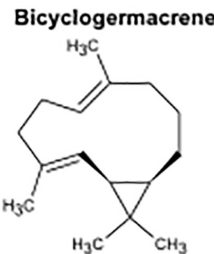<smiles>CC(C)(C)COc1cc(-c2oc3cc(O)cc(O)c3c(=O)c2OC2OC3OC(O2)C(O)C(O)C3O)ccc1O</smiles>

FIGURE 1 | Structure of botanical molecules with antiviral activity against herpes simplex viruses. Structure of molecules derived from (A) algae, (B) fungi and (C) plants that have been reported to have antiviral activity against HSV-1, HSV-2 or both viruses. Molecular structures were drawn using ACD/ChemSketch ${ }^{T M}$, (version 2018.1.1, Advanced Chemistry Development, Inc., Toronto, ON, Canada, www.acdlabs.com, 2019). Griffithsin (Protein Data Bank accession number 2GUD) was modeled using PyMOL ${ }^{\mathrm{TM}}$ (Molecular Graphics System, Version 1.3, Schrödinger, LLC).

Another example of an alga with antiviral effects against HSV is Hypnea musciformis, a red seaweed present in Italy, which has shown strong antiviral activity against HSV-1, even in different aqueous fractions obtained from its processing. Several mechanisms of action for these preparations were identified, such as virucidal activity and the inhibition of virus binding into the cell (Mendes et al., 2012). Other reports have also described antiviral effects for different algae extracts against HSVs, such as Xalas, a derivative of Scinaia hatei that has antiviral activity against HSV-1 and HSV-2, which inhibits the entry of 
the virus into the cell, and is likely mediated by sulfated xylans present in the extract (Figure 1) (Damonte et al., 2009). On the other hand, Osmundaria obtusiloba, an algae obtained from the Brazilian coast was reported to have antiviral activity against both, HSV-1 and HSV-2, which was suggested to be mediated by algae glycolipids interacting with viral glycoproteins (Souza et al., 2012). Padina pavonia, another algae that inhibits HSV-1 replication, has been reported to have a bioactive compound consisting of sulfated polysaccharides (fucoidan) that hampers the binding of the virus to the surface of the cell (Figure 1) (Hayashi et al., 2008).

Extracts derived from the green microalga Haematococcus pluvialis have also shown anti-herpetic activity. Extracts obtained from this microalga through pressurized liquid extraction displayed inhibitory action against HSV-1 replication, which was suggested to be mediated by an inhibition in the attachment of the virus to the host cell, the virus-cell fusion process and/or virus entry into the cell (Santoyo et al., 2012). Another example of an alga extract with antiviral activity against HSV-1 was obtained from Cystoseira myrica, which strongly inhibits the replication of this virus (Zandi et al., 2007).

Interestingly, researchers have isolated and studied a chemically modified polysaccharide from the green alga Enteromorpha compressa with anti HSV-1 activity (Figure 1). Notably, this study reported total viral inhibition when the evaluated compound was added to human Hep-2 cells infected with a clinical isolate of HSV-1 in a time-of-addition assay. Because the effect was maintained when applied post-treatment, the authors suggested that the antiviral activity might be mediated by the inhibition of virus replication and/or viral protein synthesis (Lopes et al., 2017).

Another alga which has been studied is Eucheuma gelatinae, a red alga that is widespread in tropical and subtropical regions. Polysaccharides obtained from this organism were tested for their antiviral activity against HSV in vitro using Vero cells infected with ACV-sensitive or ACV-resistant HSV-1 and HSV-2 isolates (Figure 1). In this study, strong antiviral activity against HSV was observed in early stages of infection affecting the attachment of HSV. Additionally, it was shown experimentally that viral protein synthesis was affected through the evaluation of the expression of the viral protein VP5, as well as the cellular localization of this protein which is normally found in the nucleus. After the treatment with the alga extract, VP5 was mainly found in the cytoplasm (Jin et al., 2015). Table 2 summarizes the antiviral activity of these compounds.

\section{Algae-Derived Compounds With Antiviral Activity Against HSVs in Animal Models}

Griffithsin is a lectin extracted from the red alga Griffithsia sp., which has been shown to be capable of inhibiting HSV infection in a murine model of HSV-2 infection (Figure 1) (Nixon et al., 2013). The mechanism of action of Griffithsin consists on its binding to mannose $\mathrm{N}$-glycosylations that blocks the infection process of HSV-2 and inhibits cell-tocell spread of the virus. The results with this compound have been promising and its effectiveness is expected to be evaluated in humans in the near future. Additionally, Griffithsin has been evaluated as an antiviral in combination with carrageenan both, in cell cultures and in animals to evaluate the potential synergic effect of the two compounds against HSV-2 in a murine model of infection. The study showed a strong reduction in HSV-2 infection when applied together as a prophylactic, namely between $10 \mathrm{~min}$ and $1 \mathrm{~h}$ prior to infection (Levendosky et al., 2015). A more recent article reported the efficacy of Griffithsin in combination with carrageenan against HSV-2 infections together with HPV and HIV-1, which was evaluated in both, a murine and rhesus macaque model using a vaginal fast-dissolving insert (Derby et al., 2018). This study showed that a fast-dissolving vaginal insert with low moisture content is able to protect against SHIV in macaques, while in mice it showed promising results protecting against HSV-2 and HPV.

Notably, Symphyocladia latiuscula is a red macroalga that has been reported to produce compounds with virucidal antiviral activity against HSV-1 (Figure 1). Vero cells infected with HSV-1 and treated with extracts from this microalga showed reduced plaque formation. The antiviral effect of these compounds has also been evaluated in a murine model skin infection, which showed decreased skin lesions compared to controls when administrated $4 \mathrm{~h}$ before infection and then three times per day for 6-10 days. Also, skin obtained from these treated and infected animals showed lesser plaque forming units than the control (Park et al., 2014).

On the other hand, Hayashi and colleagues reported that fucoidan from the brown macroalga Undaria pinnatifida, which are sulfated polysaccharide, have antiviral activity against HSV-1 and HSV-2 that is mediated by hampering the binding of the virus to the cell surface (Figure 1) (Lee et al., 2004). When the effect of fucoidan was tested in another study against corneal infection with HSV-1, a reduction in herpetic lesions was found in those animals that received pretreatments with fucoidan during 1 week (Hayashi et al., 2008). Finally, a study performed by Alboofetileh et al. (2019), showed that fucoidans extracted from the brown seaweed Nizamuddinia zanardinii exert strong antiviral activity against HSV-2 infection. They found that an algal extract containing this compound inhibited the attachment of HSV-2 to Vero cells, inhibiting the early phase of HSV-2 infection (Alboofetileh et al., 2019). Table 2 summarizes the antiviral activity of these compounds.

Another study reported that chemically modified polysaccharides from the green algae $E$. compressa of the Ulvaceae family, has antiviral activity against HSV-1 infection. In this work the green algae was processed and chemically modified polysaccharides were purified and tested in plaque reduction assays, determining an antiviral effect mediated after virus penetration (Lopes et al., 2017).

Interestingly, a recent article showed antiviral activity against HSV-2 for two purified sulfated polysaccharides isolated from the brown alga Sargassum henslowianum, a species found in southeastern China and Asia (Sun et al., 2019). In this work, algae extracts were treated to purify the polysaccharides named SHAP-1 and SHAP-2, which were later evaluated in viral plaque formation assay for both HSV-1 and HSV-2 virus. However, 
TABLE 2 | Botanical compounds and extracts with antiviral activity against HSV-1 and HSV-2.

\begin{tabular}{|c|c|c|c|c|c|c|}
\hline $\begin{array}{l}\text { Species } \\
\text { (common name) }\end{array}$ & Mechanism of action & $\begin{array}{l}\text { Virus } \\
\text { assessed }\end{array}$ & $\begin{array}{l}\text { Assessed in cell } \\
\text { cultures }\end{array}$ & $\begin{array}{l}\text { Assessed in } \\
\text { animal models }\end{array}$ & Active molecule & References \\
\hline \multicolumn{7}{|l|}{ Algae } \\
\hline $\begin{array}{l}\text { Hypnea } \\
\text { musciformis } \\
\text { (Hooked Weed) }\end{array}$ & $\begin{array}{l}\text { Virucidal, inhibition of viral } \\
\text { binding, inhibition of viral } \\
\text { entry }\end{array}$ & HSV-1 & $\checkmark$ & $\begin{array}{l}\text { Unknown or not } \\
\text { reported }\end{array}$ & $\begin{array}{l}\text { Unknown or not } \\
\text { reported }\end{array}$ & Mendes et al., 2012 \\
\hline $\begin{array}{l}\text { Stypopodium } \\
\text { zonale (Ochrophyta) }\end{array}$ & Unknown or not reported & HSV-1 & $\checkmark$ & $\begin{array}{l}\text { Unknown or not } \\
\text { reported }\end{array}$ & Atomaric acid & Ribeiro et al., 2012 \\
\hline Scinaia hatei & Inhibition of viral entry & $\begin{array}{l}\text { HSV-1 and } \\
\text { HSV-2 }\end{array}$ & $\checkmark$ & $\begin{array}{l}\text { Unknown or not } \\
\text { reported }\end{array}$ & $\begin{array}{l}\text { Xylan }(1,4-\beta-D- \\
\text { xylopyranosyl) }\end{array}$ & $\begin{array}{l}\text { Damonte et al., } \\
2009\end{array}$ \\
\hline $\begin{array}{l}\text { Osmundaria } \\
\text { obtusiloba }\end{array}$ & $\begin{array}{l}\text { Interaction with viral } \\
\text { glycoproteins }\end{array}$ & $\begin{array}{l}\text { HSV-1 and } \\
\text { HSV-2 }\end{array}$ & $\checkmark$ & $\begin{array}{l}\text { Unknown or not } \\
\text { reported }\end{array}$ & $\begin{array}{l}\text { Sulfoquinovosyldia } \\
\text { cylglycerol }\end{array}$ & Souza et al., 2012 \\
\hline $\begin{array}{l}\text { Padina pavonica } \\
\text { (Peacock's Tail) }\end{array}$ & Inhibition of viral binding & HSV-1 & $\checkmark$ & $\checkmark$ & Fucoidan & Hayashi et al., 2008 \\
\hline $\begin{array}{l}\text { Haematococcus } \\
\text { pluvialis }\end{array}$ & $\begin{array}{l}\text { Inhibition of viral binding, } \\
\text { inhibition of viral entry }\end{array}$ & HSV-1 & $\checkmark$ & $\begin{array}{l}\text { Unknown or not } \\
\text { reported }\end{array}$ & $\begin{array}{l}\text { Unknown or not } \\
\text { reported }\end{array}$ & $\begin{array}{l}\text { Santoyo et al., } \\
2012\end{array}$ \\
\hline $\begin{array}{l}\text { Cystoseira myrica } \\
\text { (False Sargassum) }\end{array}$ & $\begin{array}{l}\text { Viral inhibition before and } \\
\text { after absorption }\end{array}$ & HSV-1 & $\checkmark$ & $\begin{array}{l}\text { Unknown or not } \\
\text { reported }\end{array}$ & $\begin{array}{l}\text { Unknown or not } \\
\text { reported }\end{array}$ & Zandi et al., 2007 \\
\hline $\begin{array}{l}\text { Enteromorpha } \\
\text { compressa }\end{array}$ & $\begin{array}{l}\text { Inhibition of viral replication, } \\
\text { inhibition of viral protein } \\
\text { synthesis }\end{array}$ & HSV-1 & $\checkmark$ & $\begin{array}{l}\text { Unknown or not } \\
\text { reported }\end{array}$ & $\begin{array}{l}\text { Sulfated } \\
\text { polysaccharides }\end{array}$ & Lopes et al., 2017 \\
\hline $\begin{array}{l}\text { Eucheuma } \\
\text { gelatinae (Guso) }\end{array}$ & $\begin{array}{l}\text { Virucidal, inhibition of viral } \\
\text { binding, inhibition of viral } \\
\text { gene expression }\end{array}$ & HSV-1 & $\checkmark$ & $\begin{array}{l}\text { Unknown or not } \\
\text { reported }\end{array}$ & $\begin{array}{l}\text { Sulfated } \\
\text { polysaccharides }\end{array}$ & Jin et al., 2015 \\
\hline $\begin{array}{l}\text { Griffithsia sp. } \\
\text { (Griffiths's Coral } \\
\text { Weed) }\end{array}$ & $\begin{array}{l}\text { Inhibition of viral binding, } \\
\text { inhibition of viral entry }\end{array}$ & HSV-2 & $\checkmark$ & $\checkmark$ & Griffithsin & $\begin{array}{l}\text { Nixon et al., 2013; } \\
\text { Levendosky et al., } \\
\text { 2015; Derby et al., } \\
2018\end{array}$ \\
\hline $\begin{array}{l}\text { Symphyocladia } \\
\text { latiuscula }\end{array}$ & Virucidal & HSV-1 & $\checkmark$ & $\checkmark$ & $\begin{array}{l}\text { 2,3,6-tribromo-4,5- } \\
\text { dihydroxybenzyl } \\
\text { methyl ether }\end{array}$ & Park et al., 2014 \\
\hline $\begin{array}{l}\text { Undaria pinnatifida } \\
\text { (Wakame) }\end{array}$ & Inhibition of viral binding & $\begin{array}{l}\text { HSV-1 and } \\
\text { HSV-2 }\end{array}$ & $\checkmark$ & $\checkmark$ & Fucoidan & $\begin{array}{l}\text { Hayashi et al., } \\
\text { 2008; Lee et al., } \\
2004\end{array}$ \\
\hline \multicolumn{7}{|l|}{ Fungi } \\
\hline Aspergillus ruber & $\begin{array}{l}\text { Inhibition of viral binding, } \\
\text { inhibition of entry }\end{array}$ & HSV-1 & $\checkmark$ & $\begin{array}{l}\text { Unknown or not } \\
\text { reported }\end{array}$ & $\begin{array}{l}\text { Isodihydroauroglaucin } \\
\text { Flavoglaucin }\end{array}$ & Liang et al., 2018 \\
\hline $\begin{array}{l}\text { Aspergillus } \\
\text { versicolor }\end{array}$ & Unknown or not reported & HSV-1 & $\checkmark$ & $\begin{array}{l}\text { Unknown or not } \\
\text { reported }\end{array}$ & Anthraquinones & Huang et al., 2017 \\
\hline Scytalidium & Virucidal & $\begin{array}{l}\text { HSV-1 and } \\
\text { HSV-2 }\end{array}$ & $\checkmark$ & $\begin{array}{l}\text { Unknown or not } \\
\text { reported }\end{array}$ & Halovirs A - E & Rowley et al., 2003 \\
\hline Inonotus obliquus & $\begin{array}{l}\text { Inhibition of viral binding, } \\
\text { inhibition of viral entry }\end{array}$ & HSV-1 & $\checkmark$ & $\begin{array}{l}\text { Unknown or not } \\
\text { reported }\end{array}$ & $\begin{array}{l}\text { aqueous extract } \\
\text { from Inonotus } \\
\text { obliquus (AEIO) }\end{array}$ & $\begin{array}{l}\text { Pradeep et al., } \\
2019\end{array}$ \\
\hline $\begin{array}{l}\text { Ganoderma } \\
\text { lucidum (Lingzhi } \\
\text { Mushroom) }\end{array}$ & $\begin{array}{l}\text { Inhibition of viral binding, } \\
\text { inhibition of viral entry }\end{array}$ & $\begin{array}{l}\text { HSV-1 and } \\
\text { HSV-2 }\end{array}$ & $\checkmark$ & $\begin{array}{l}\text { Unknown or not } \\
\text { reported }\end{array}$ & Polysaccharides & Eo et al., 2000 \\
\hline $\begin{array}{l}\text { Agaricus } \\
\text { brasiliensis (Almond } \\
\text { Mushroom) }\end{array}$ & $\begin{array}{l}\text { Inhibition of viral binding, } \\
\text { inhibition of viral entry }\end{array}$ & $\begin{array}{l}\text { HSV-1 and } \\
\text { HSV-2 }\end{array}$ & $\begin{array}{l}\text { Unknown or not } \\
\text { reported }\end{array}$ & $\checkmark$ & Polysaccharides & $\begin{array}{l}\text { Cardozo et al., } \\
2013\end{array}$ \\
\hline $\begin{array}{l}\text { Grifola frondosa } \\
\text { (Maltake) }\end{array}$ & Virucidal & HSV-1 & $\checkmark$ & $\checkmark$ & Protein & Gu et al., 2007 \\
\hline Rozites caperata & Unknown or not reported & HSV-1 & $\checkmark$ & $\checkmark$ & Peptides & $\begin{array}{l}\text { Pradeep et al., } \\
2019\end{array}$ \\
\hline \multicolumn{7}{|l|}{ Plants } \\
\hline $\begin{array}{l}\text { Peganum harmala } \\
\text { (Wild Rue) }\end{array}$ & Inhibition of viral entry & HSV-2 & $\checkmark$ & $\begin{array}{l}\text { Unknown or not } \\
\text { reported }\end{array}$ & Harmine & $\begin{array}{l}\text { Benzekri et al., } \\
2018\end{array}$ \\
\hline $\begin{array}{l}\text { Melia azedarach } \\
\text { (Chinaberry Tree) }\end{array}$ & Unknown or not reported & $\begin{array}{l}\text { HSV-1 and } \\
\text { HSV-2 }\end{array}$ & $\checkmark$ & $\checkmark$ & $\begin{array}{l}\text { Meliacine } \\
\text { (Glycopeptide) }\end{array}$ & $\begin{array}{l}\text { Petrera and Coto, } \\
\text { 2009; Barquero } \\
\text { et al., } 1997\end{array}$ \\
\hline
\end{tabular}


TABLE 2 | Continued

\begin{tabular}{|c|c|c|c|c|c|c|}
\hline $\begin{array}{l}\text { Species } \\
\text { (common name) }\end{array}$ & Mechanism of action & $\begin{array}{l}\text { Virus } \\
\text { assessed }\end{array}$ & $\begin{array}{l}\text { Assessed in cell } \\
\text { cultures }\end{array}$ & $\begin{array}{l}\text { Assessed in } \\
\text { animal models }\end{array}$ & Active molecule & References \\
\hline Labiatae & $\begin{array}{l}\text { Virucidal, inhibition of viral } \\
\text { binding, inhibition of viral } \\
\text { entry }\end{array}$ & $\begin{array}{l}\text { HSV-1 and } \\
\text { HSV-2 }\end{array}$ & $\checkmark$ & $\begin{array}{l}\text { Unknown or not } \\
\text { reported }\end{array}$ & $\begin{array}{l}\text { Unknown or not } \\
\text { reported }\end{array}$ & Brand et al., 2016 \\
\hline Verbenaceae & $\begin{array}{l}\text { Virucidal, inhibition of viral } \\
\text { binding, inhibition of viral } \\
\text { entry }\end{array}$ & $\begin{array}{l}\text { HSV-1 and } \\
\text { HSV-2 }\end{array}$ & $\checkmark$ & $\begin{array}{l}\text { Unknown or not } \\
\text { reported }\end{array}$ & $\begin{array}{l}\text { Unknown or not } \\
\text { reported }\end{array}$ & Brand et al., 2016 \\
\hline Glechon marifolia & $\begin{array}{l}\text { Inhibition after viral } \\
\text { attachment }\end{array}$ & HSV-1 & $\checkmark$ & $\begin{array}{l}\text { Unknown or not } \\
\text { reported }\end{array}$ & Bicyclogermacrene & Venturi et al., 2015 \\
\hline $\begin{array}{l}\text { Aglaia odorata } \\
\text { (Chinese Perfume } \\
\text { Plant) }\end{array}$ & $\begin{array}{l}\text { Inhibition after viral } \\
\text { attachment }\end{array}$ & HSV-1 & $\begin{array}{l}\text { Unknown or not } \\
\text { reported }\end{array}$ & $\checkmark$ & $\begin{array}{l}\text { Unknown or not } \\
\text { reported }\end{array}$ & Lipipun et al., 2003 \\
\hline $\begin{array}{l}\text { Morus alba (White } \\
\text { Mulberry) }\end{array}$ & $\begin{array}{l}\text { Inhibition of early stages of } \\
\text { viral infection }\end{array}$ & $\begin{array}{l}\text { HSV-1 and } \\
\text { HSV-2 }\end{array}$ & $\checkmark$ & $\begin{array}{l}\text { Unknown or not } \\
\text { reported }\end{array}$ & Kuwanon X & Ma et al., 2016 \\
\hline $\begin{array}{l}\text { Houttuynia cordata } \\
\text { (Fish Mint) }\end{array}$ & $\begin{array}{l}\text { Inhibition of NF-kB } \\
\text { activation, inhibition of viral } \\
\text { binding, inhibition of viral } \\
\text { entry }\end{array}$ & $\begin{array}{l}\text { HSV-1 and } \\
\text { HSV-2 }\end{array}$ & $\checkmark$ & $\begin{array}{l}\text { Unknown or not } \\
\text { reported }\end{array}$ & $\begin{array}{l}\text { Quercitin, } \\
\text { Isoquercitrin and } \\
\text { Quercitrin }\end{array}$ & $\begin{array}{l}\text { Chen et al., } 2011 \\
\text { and Hung et al., } \\
2015\end{array}$ \\
\hline $\begin{array}{l}\text { Veratum } \\
\text { grandiflorum }\end{array}$ & Inhibition of viral replication & $\begin{array}{l}\text { HSV-1 and } \\
\text { HSV-2 }\end{array}$ & $\checkmark$ & $\begin{array}{l}\text { Unknown or not } \\
\text { reported }\end{array}$ & Resveratrol & $\begin{array}{l}\text { Faith et al., 2006; } \\
\text { Leyton et al., } 2015\end{array}$ \\
\hline $\begin{array}{l}\text { Eucalyptus } \\
\text { camaldulensis } \\
\text { (River Red Gum) }\end{array}$ & $\begin{array}{l}\text { Inhibition before and after } \\
\text { virus adsorption }\end{array}$ & $\begin{array}{l}\text { HSV-1 and } \\
\text { HSV-2 }\end{array}$ & $\checkmark$ & $\begin{array}{l}\text { Unknown or not } \\
\text { reported }\end{array}$ & $\begin{array}{l}\text { Unknown or not } \\
\text { reported }\end{array}$ & Mahmoud, 2017 \\
\hline $\begin{array}{l}\text { Eucalyptus } \\
\text { sideroxylon } \\
\text { (Mugga) }\end{array}$ & $\begin{array}{l}\text { Virucidal, inhibition of viral } \\
\text { entry, post-infection antiviral } \\
\text { effects }\end{array}$ & $\begin{array}{l}\text { HSV-1 and } \\
\text { HSV-2 }\end{array}$ & $\checkmark$ & $\begin{array}{l}\text { Unknown or not } \\
\text { reported }\end{array}$ & $\begin{array}{l}\text { Unknown or not } \\
\text { reported }\end{array}$ & Okba et al., 2017 \\
\hline $\begin{array}{l}\text { Aristotelia chilensis } \\
\text { (Chilean Wineberry) }\end{array}$ & $\begin{array}{l}\text { Inhibition after virus } \\
\text { adsorption }\end{array}$ & HSV-2 & $\checkmark$ & $\begin{array}{l}\text { Unknown or not } \\
\text { reported }\end{array}$ & $\begin{array}{l}\text { Unknown or not } \\
\text { reported }\end{array}$ & $\begin{array}{l}\text { Pacheco et al., } \\
1993\end{array}$ \\
\hline $\begin{array}{l}\text { Drymis winteri } \\
\text { (Winter's Bark) }\end{array}$ & $\begin{array}{l}\text { Inhibition after virus } \\
\text { adsorption }\end{array}$ & HSV-2 & $\checkmark$ & $\begin{array}{l}\text { Unknown or not } \\
\text { reported }\end{array}$ & $\begin{array}{l}\text { Unknown or not } \\
\text { reported }\end{array}$ & $\begin{array}{l}\text { Pacheco et al., } \\
1993\end{array}$ \\
\hline $\begin{array}{l}\text { Elytropus chilensis } \\
\text { (Quilmay) }\end{array}$ & $\begin{array}{l}\text { Inhibition after virus } \\
\text { adsorption }\end{array}$ & HSV-2 & $\checkmark$ & $\begin{array}{l}\text { Unknown or not } \\
\text { reported }\end{array}$ & $\begin{array}{l}\text { Unknown or not } \\
\text { reported }\end{array}$ & $\begin{array}{l}\text { Pacheco et al., } \\
1993\end{array}$ \\
\hline $\begin{array}{l}\text { Luma apiculata } \\
\text { (Chilean Myrtle) }\end{array}$ & $\begin{array}{l}\text { Inhibition after virus } \\
\text { adsorption }\end{array}$ & HSV-2 & $\checkmark$ & $\begin{array}{l}\text { Unknown or not } \\
\text { reported }\end{array}$ & $\begin{array}{l}\text { Unknown or not } \\
\text { reported }\end{array}$ & $\begin{array}{l}\text { Pacheco et al., } \\
1993\end{array}$ \\
\hline $\begin{array}{l}\text { Quillaja saponaria } \\
\text { (Soap Bark Tree) }\end{array}$ & $\begin{array}{l}\text { Virucidal, inhibition of virus } \\
\text { binding, inhibition of virus } \\
\text { entry }\end{array}$ & HSV-1 & $\checkmark$ & $\begin{array}{l}\text { Unknown or not } \\
\text { reported }\end{array}$ & $\begin{array}{l}\text { Unknown or not } \\
\text { reported }\end{array}$ & Roner et al., 2007 \\
\hline $\begin{array}{l}\text { Melaleuca } \\
\text { alternifolia (Tea Tree) }\end{array}$ & $\begin{array}{l}\text { Inhibition of virus binding, } \\
\text { inhibition of virus entry }\end{array}$ & $\begin{array}{l}\text { HSV-1 and } \\
\text { HSV-2 }\end{array}$ & $\checkmark$ & $\begin{array}{l}\text { Unknown or not } \\
\text { reported }\end{array}$ & $\begin{array}{l}\text { Unknown or not } \\
\text { reported }\end{array}$ & $\begin{array}{l}\text { Garozzo et al., } \\
2009\end{array}$ \\
\hline $\begin{array}{l}\text { Melissa officinalis } \\
\text { (Balm Mint) }\end{array}$ & Unknown or not reported & HSV-2 & $\checkmark$ & $\begin{array}{l}\text { Unknown or not } \\
\text { reported }\end{array}$ & $\begin{array}{l}\text { Unknown or not } \\
\text { reported }\end{array}$ & $\begin{array}{l}\text { Allahverdiyev et al., } \\
2004\end{array}$ \\
\hline $\begin{array}{l}\text { Alpinia officinarum } \\
\text { (Lesser Galangal) }\end{array}$ & $\begin{array}{l}\text { Inhibition after virus } \\
\text { adsorption }\end{array}$ & HSV-1 & $\checkmark$ & $\checkmark$ & $\begin{array}{l}\text { Unknown or not } \\
\text { reported }\end{array}$ & $\begin{array}{l}\text { Kurokawa et al., } \\
1995\end{array}$ \\
\hline $\begin{array}{l}\text { Geum japonicum } \\
\text { (Asian Herb Bennet) }\end{array}$ & $\begin{array}{l}\text { Inhibition after virus } \\
\text { adsorption }\end{array}$ & HSV-1 & $\checkmark$ & $\checkmark$ & $\begin{array}{l}\text { Unknown or not } \\
\text { reported }\end{array}$ & $\begin{array}{l}\text { Kurokawa et al., } \\
1995\end{array}$ \\
\hline
\end{tabular}


TABLE 2 | Continued

\begin{tabular}{|c|c|c|c|c|c|c|}
\hline $\begin{array}{l}\text { Species } \\
\text { (common name) }\end{array}$ & Mechanism of action & $\begin{array}{l}\text { Virus } \\
\text { assessed }\end{array}$ & $\begin{array}{l}\text { Assessed in cell } \\
\text { cultures }\end{array}$ & $\begin{array}{l}\text { Assessed in } \\
\text { animal models }\end{array}$ & Active molecule & References \\
\hline $\begin{array}{l}\text { Paeonia } \\
\text { suffruticosa } \\
\text { (Mudan) }\end{array}$ & $\begin{array}{l}\text { Inhibition after virus } \\
\text { adsorption }\end{array}$ & HSV-1 & $\checkmark$ & $\checkmark$ & $\begin{array}{l}\text { Unknown or not } \\
\text { reported }\end{array}$ & $\begin{array}{l}\text { Kurokawa et al., } \\
1995\end{array}$ \\
\hline $\begin{array}{l}\text { Phellodendron } \\
\text { amurense (Amur } \\
\text { Cork Tree) }\end{array}$ & $\begin{array}{l}\text { Inhibition after virus } \\
\text { adsorption }\end{array}$ & HSV-1 & $\checkmark$ & $\checkmark$ & $\begin{array}{l}\text { Unknown or not } \\
\text { reported }\end{array}$ & $\begin{array}{l}\text { Kurokawa et al., } \\
1995\end{array}$ \\
\hline $\begin{array}{l}\text { Polygala tenuifolia } \\
\text { (Yuan Zhi) }\end{array}$ & $\begin{array}{l}\text { Inhibition after virus } \\
\text { adsorption }\end{array}$ & HSV-1 & $\checkmark$ & $\checkmark$ & $\begin{array}{l}\text { Unknown or not } \\
\text { reported }\end{array}$ & $\begin{array}{l}\text { Kurokawa et al., } \\
1995\end{array}$ \\
\hline $\begin{array}{l}\text { Polygonum } \\
\text { cuspidatum (Asian } \\
\text { Knotweed) }\end{array}$ & $\begin{array}{l}\text { Inhibition after virus } \\
\text { adsorption }\end{array}$ & HSV-1 & $\checkmark$ & $\checkmark$ & $\begin{array}{l}\text { Unknown or not } \\
\text { reported }\end{array}$ & $\begin{array}{l}\text { Kurokawa et al., } \\
1995\end{array}$ \\
\hline $\begin{array}{l}\text { Rhus javanica (Java } \\
\text { Brucea) }\end{array}$ & $\begin{array}{l}\text { Inhibition after virus } \\
\text { adsorption }\end{array}$ & HSV-1 & $\checkmark$ & $\checkmark$ & $\begin{array}{l}\text { Unknown or not } \\
\text { reported }\end{array}$ & $\begin{array}{l}\text { Kurokawa et al., } \\
1995\end{array}$ \\
\hline $\begin{array}{l}\text { Syzygium } \\
\text { aromaticum (Clove) }\end{array}$ & $\begin{array}{l}\text { Inhibition after virus } \\
\text { adsorption }\end{array}$ & HSV-1 & $\checkmark$ & $\checkmark$ & $\begin{array}{l}\text { Unknown or not } \\
\text { reported }\end{array}$ & $\begin{array}{l}\text { Kurokawa et al., } \\
1995\end{array}$ \\
\hline $\begin{array}{l}\text { Terminalia arjuna } \\
\text { (Arjun Tree) }\end{array}$ & $\begin{array}{l}\text { Inhibition after virus } \\
\text { adsorption }\end{array}$ & HSV-1 & $\checkmark$ & $\checkmark$ & $\begin{array}{l}\text { Unknown or not } \\
\text { reported }\end{array}$ & $\begin{array}{l}\text { Kurokawa et al., } \\
1995\end{array}$ \\
\hline $\begin{array}{l}\text { Terminalia chebula } \\
\text { (Black Myrobalan) }\end{array}$ & $\begin{array}{l}\text { Inhibition after virus } \\
\text { adsorption }\end{array}$ & HSV-1 & $\checkmark$ & $\checkmark$ & $\begin{array}{l}\text { Unknown or not } \\
\text { reported }\end{array}$ & $\begin{array}{l}\text { Kurokawa et al., } \\
1995\end{array}$ \\
\hline $\begin{array}{l}\text { Alternanthera } \\
\text { philoxeroides } \\
\text { (Alligator Weed) }\end{array}$ & Virucidal & $\begin{array}{l}\text { HSV-1 and } \\
\text { HSV-2 }\end{array}$ & $\checkmark$ & $\checkmark$ & $\begin{array}{l}\text { Chikusetsusaponin } \\
\text { IV }\end{array}$ & $\begin{array}{l}\text { Rattanathongkom } \\
\text { et al., } 2009\end{array}$ \\
\hline
\end{tabular}

following experiments in this research article focused on HSV-2 rather than HSV-1, arguing greater clinical value for the former (Sun et al., 2019). Time-of-addition assays, as well and adsorption and penetration assays suggest an antiviral effect at early stages of infection (Sun et al., 2019).

\section{Fungus-Derived Compounds With Antiviral Activity Against HSVs in Cell Cultures}

Fungus-derived compounds have also been explored for identifying novel molecules with antiviral activity against HSV-1 and HSV-2. The fungus Aspergillus versicolor has been shown to produce secondary metabolites, such as anthraquinones with anti-herpetic activity (Figure 1). In the study by Huang et al. (2017), three anthraquinones were found to have antiviral effects against HSV-1 in vitro using Vero cells. Another fungus of the Aspergillus genus showed antiviral activity against HSV-1, with two secondary metabolites flavoglaucin and isodihydroauroglaucin derived from $A$. ruber being assessed, and two compounds showing anti-HSV-1 effects (Figure 1) (Liang et al., 2018). In another study, peptides produced by the marine-derived fungus Scytalidium were found to have antiviral activity against HSV-1 and HSV-2, particularly by a peptide named Halovir, which was suggested to have virucidal activity when in direct contact with HSV-1 and HSV-2 (Figure 1) (Rowley et al., 2003).

Furthermore, an aqueous extract from Inonotus obliquus (AEIO) was shown to inhibit HSV-1 infection in Vero cells (Pradeep et al., 2019). the antiviral activity was detected at early times during viral infection, suggesting AEIO blocks viral entry, particularly membrane fusion (Pradeep et al., 2019).
Interestingly, fungus proteins that inhibit HSV infection have also been identified. Two proteins that bind polysaccharides from the mushroom Ganoderma lucidum were found to have antiviral effects against HSV-1 and HSV-2. One was named the neutral protein bound to polysaccharide (NPBP) and the other the acidic protein bound to polysaccharide (APBP). Although APBP had more potent antiviral activity than NPBP, both inhibited plaque formation by both types of HSV. Interestingly, it was found that the mechanism of action of APBP was mediated by the inhibition of the attachment and penetration of the virus into Vero cells (Eo et al., 2000). Table 2 summarizes the antiviral activity of these compounds.

\section{Fungus-Derived Compounds With Antiviral Activity Against HSVs in Animal Models}

Sulfated compounds isolated from a polysaccharide (MI-S) derived from Agaricus brasiliensis have shown antiherpetic activity against HSV-1 and HSV-2 (De Sousa Cardozo et al., 2014). MI-S inhibited viral adsorption and penetration into Vero cells and had a synergistic effect with acyclovir (De Sousa Cardozo et al., 2014). Interestingly, this compound was also shown to reduce the severity of HSV-2 disease in a murine genital infection model with one single application (Cardozo et al., 2013).

On the other hand, Qing et al., reported that a protein from Grifola frondosa (GFAHP) had antiviral activity against HSV-1, which was shown to have virucidal effects in cell cultures and suppressed viral entry into Vero cells (Gu et al., 2007). Furthermore, GFAHP also showed antiviral activity against HSV-1 in animals when applied topically to the cornea of 
mice. Mice treated with GFAHP had a significant reduction in blepharitis, vascularization and stromal disease, as well as reduced viral replication in the cornea (Gu et al., 2007). Notably, the antiviral protein RC28 obtained from the fungus Rozites caperata showed antiviral activity against HSV-1 in Vero cells (Pradeep et al., 2019). Moreover, the authors evaluated the antiviral effect of RC28 in an animal model and observed that this peptide decreased the severity of stromal keratitis (Pradeep et al., 2019). Table 2 summarizes the antiviral activity of these compounds.

\section{Plant-Derived Compounds With Antiviral Activity Against HSVs in Cell Cultures}

Plant extracts have received particular attention when searching for new molecules with anti-herpetic activity (Li et al., 2017; Akram et al., 2018). Interestingly, numerous plant-derived extracts and compounds have been reported to inhibit HSV replication. For instance, organic extracts belonging to the Peganum harmala species have been described to have antiviral activity against HSV-2 and to interfere with virus entry (Benzekri et al., 2018).

Essential oils extracted from plants belonging to the Labiatae and Verbenaceae families have also been shown to have antiviral activity against HSV. Vero cells incubated with HSV and plantextracted essential oils for 48-72 h significantly reduced HSV-1 and HSV-2 viral titers. Interestingly, their mechanisms of action were found to be related to the pre-infective stages (Brand et al., 2016). Another study that also assessed essentials oils, but extracted from Glechon spathulata and Glechon marifolia identified antiviral activity against HSV-1, which was effective after the infection of Vero cells (Figure 1) (Venturi et al., 2015). Eucalyptus essential oils are used to treat symptoms during cough and bronchitis, in numerous presentations, such as ointments, liniments, in oral form and in vapor baths as inhalants (Kaur et al., 2013). The main components of the essential oils from the Eucalyptus species are cineole and alphapinene (Sebei et al., 2015). One study evaluated the Australian tea tree oil and Eucalyptus oil over HSV and reported antiviral activity against both, HSV-1 and HSV-2. Treatments before, during or post-infection determined that these compounds had virucidal activity affecting the virus before or during adsorption, before the virus had entered the cells (Schnitzler et al., 2001). Ethanolic extracts from the leaves of E. camaldulensis were shown to inhibit HSV-1 and HSV-2 infection when the extracts were added to Vero cells during- and post-infection. Additionally, in this study a synergistic effect between acyclovir and the ethanolic extracts was reported in cell cultures (Abu-Jafar and Mahmoud, 2017). In another study, researchers reported 24 new metabolites in the leaves of E. sideroxylon and four new metabolites within the genus Eucalyptus that have antiviral activity using an ultra-performance liquid chromatography coupled to photodiode-array and electrospray ionization mass spectrometer (UPLC/PDA/ESI-qTOF-MS). Within the antiviral activities detected, there were compounds that also inhibited hepatitis A, coxsackie and adenoviruses, besides HSV-1 and HSV-2. Interestingly, the highest antiviral activity was observed against HSV-2, with the antiviral effect acting pre-treatment (virucidal), thus inhibiting virus entry and subsequent infection processes, while the antiviral effect against HSV-1 was only observed when the extract was incubated with the virus previous to the cell infection (Okba et al., 2017). In addition, twelve compounds isolated from the leaves and twigs of E. globulus were found to have antiviral activity against HSV-1 and HSV-2. In this study, Tereticornate A was identified to have the greatest activity against HSV-1, which was higher than acyclovir. Cypellocarpin $\mathrm{C}$ displayed the strongest antiviral activity against HSV-2, greater than that observed for acyclovir (Brezáni et al., 2018).

Other essential oils, particularly those obtained from the leaves of Melissa officinalis, which is better known as lemon balm, have also been shown to have antiviral activity against both, HSV-1 and HSV-2 with the antiviral activity attributed to tannins and non-tannin polyphenolic fractions within the extract (Mazzanti et al., 2008). Another study determined that volatile oils from $M$. officinalis Lamiaceae had antiviral activity against HSV-2 (Allahverdiyev et al., 2004). On the other hand, extracts from Aglaia odorata, Moringa oleifera, and Ventilago denticulate have also been shown to have antiviral activity against wild-type and drug-resistant HSV-1 isolates, yet the mechanisms of action seems to not have been identified yet, or reported (Lipipun et al., 2003).

Plants used in traditional Chinese medicine have also been tested and found to have antiviral activity (Ganjhu et al., 2015). Recently, a study reported that leaves from Mulberry (Morus alba L.), a plant that is common in Asia, has antiviral properties against HSV-1 and HSV-2. The active compound within this plant has been reported to be Kuwanon X, a stilbene polyphenol derivative, which has antiviral activity over HSV at multiple steps of the infection process, inhibiting cellular adsorption and penetration, as well as the expression of HSV1 immediate early and late genes, and the synthesis of HSV-1 DNA (Figure 1) (Ma et al., 2016). Another study showed that aqueous extracts from Houttuynia cordata, a Chinese herbal medicine, blocks HSV-2 infection by inhibiting NF- $\kappa$ B activation, a host transcription factor that has been reported to be required for effective HSV infection (Amici et al., 2006). In order to identify the compounds with antiviral activity within $H$. cordata, several flavonoid compounds in this plant were evaluated individually to determine their capacity to block the replication cycle of HSV-2. Quercetin, quercitrin, and isoquercitrin, the major flavonoid compounds found within $H$. cordata were found to be strong inhibitors of HSV-2 activity (Figure 1) (Chen et al., 2011). A subsequent study from another group determined that the mechanism of action behind the antiherpetic activity of $H$. cordata occurred at multiple levels, such as at the adsorption level, entry, post-infection acting over NF- $\kappa$ B and had virucidal activity (Hung et al., 2015). Another stilbene compound that inhibits NF- $\kappa \mathrm{B}$ activation is resveratrol, which was isolated from Veratum grandiflorum (Chen et al., 2012), and it is the main bioactive compound found in berries, peanuts, legumes and other plant-derived matrices, as well as red wine. Several studies have reported antiviral properties for this compound over the replication cycles of ACV-resistant and wild-type HSV-1 and HSV-2, both in cell 
cultures and in animal models (Figure 1) (Faith et al., 2006; Leyton et al., 2015).

Aqueous and hydroalcoholic extracts derived from native plants of Chile have also been investigated for their antiviral activity against HSV-1 and HSV-2. Hydroalcoholic extracts of Cassia stipulacea and Escallonia illinita displayed antiviral activity against HSV-1, while hydroalcoholic extracts from Aristotelia chilensis, Drymis winteri, Elytropus chilensis, as well as an aqueous extract from Luma apiculata showed antiviral activity against HSV-2. The active antiviral compounds within these preparations have not been identified or reported yet (Pacheco et al., 1993). In addition, another group determined that aqueous extracts from Quillaja saponaria, a Chilean soapbark tree that is endemic in the central zone of Chile, has antiviral activity against HSV1 and other viruses. This extract, which is currently used in food and beverages was reported to have virucidal activity by blocking the attachment of viruses to the cell surface (Roner et al., 2007). Table 2 summarizes the antiviral activity of these compounds.

\section{Plant-Derived Compounds With Antiviral Activity Against HSVs in Animal Models}

Several studies have assessed the antiviral effects of plantderived compounds against herpes simplex virus in animal models either, alone or combined with acyclovir. One of these studies found that each of the following, Geum japonicum Thunb., Rhus javanica L., Syzygium aromaticum (L.), or Terminalia chebula Retzus displayed increased antiviral activity against HSV-1 when combined with acyclovir, as compared to acyclovir alone (Kurokawa et al., 1995). On the other hand, extracts from $A$. odorata, $M$. oleifera, and $V$. denticulate were shown to have antiviral effects against HSV-1 upon cutaneous infections in $\mathrm{BALB} / \mathrm{c}$ mice. Here, the plant extracts combined with ACV and orally administered to the mice were shown to hamper the development and progression of HSV-1 skin lesions and increased the mean survival times of the animals (Lipipun et al., 2003). Chikusetsusaponin IV, a compound extracted from Alternanthera philoxeroides has shown to have antiviral activity against HSV-2 when the compound is added to the inoculum for $1 \mathrm{~h}$ before viral infection or immediately after viral infection (Rattanathongkom et al., 2009). The authors suggested that the mechanism of action of the antiviral activity action of Chikusetsusaponin IV was virucidal (Rattanathongkom et al., 2009). Moreover, Chikusetsusaponin IV showed antiviral activity against HSV2 genital infection in mice when administrated three times per day three days before infection and up to 7 days after infection (Rattanathongkom et al., 2009). Finally, Meliacine (MA) a glycopeptide obtained from Melia azedarach has been reported to have antiviral activity against acyclovirsensitive and acyclovir-resistant HSV-1 (Barquero et al., 1997). Furthermore, MA showed favorable results against HSV2 in a mouse model of infection when applied topically immediately after infection with HSV-2 (Petrera and Coto, 2009). Table 2 summarizes the antiviral activity of these compounds.

\section{CLINICAL TRIALS}

Different natural compounds have been tested in clinical trials following studies performed in animal models, in such a way to validate potential new drugs for the treatment of herpes simplex virus manifestations. Regarding herpes labialis, a Neem treebased cream (Azadirachta indica) called TheraNeem Lip Therapy that has several botanical extracts, including those obtained from organic Neem Oil, organic Coconut Oil, organic Beeswax, organic Jojoba Oil, shea Butter, sesame Oil, essential Oil of Peppermint, Vitamin E (Tocopherol) was reported to having been tested in a clinical trial (Clinicaltrials.gov Identifier NCT00985335). Regretfully, the results of this study have not been published to the best of our knowledge.

Another study involving the treatment of herpes labialis lesions was performed with Huanglian-Jiedu Decoction, a Chinese medicine formulation that includes four kinds of Chinese herbs; Huanglian (Rhizoma coptidis), Huangbo (Cortex Phellodendri), Huangqin (Scutellaria baicalensis) and Zhizi (Scutellaria baicalensis) (Clinicaltrials.gov Identifier NCT03469232). However, similar to the clinical study reported above, the results of this trial have not been published to date.

Additionally, a randomized controlled open-label superiority trial for herpes simplex virus labial episodes was recently performed with medical-grade kanuka honey (Semprini et al., 2019). Here, the botanical compound and acyclovir were applied topically as a cream up to five times a day and concluded that the medical-grade kanuka honey did not provide better efficacy than acyclovir 5\% (Semprini et al., 2019).

On the other hand, a clinical study tested VIBLOCK, which is reportedly $100 \%$ formulated with natural products, although the composition of this cream was not described (Clinicaltrials.gov Identifier NCT03080961). The formulation tested the capacity of the formulated cream to prevent HSV-2 infection. However, the results of this study have not been reported.

\section{CONCLUDING REMARKS}

Taken together, numerous botanical compounds derived from algae, fungi and plants have been reported to have strong antiviral activities both, in cell culture assays and in animal studies against herpes simplex viruses (HSV-1 and HSV-2). Interestingly, several mechanisms of action for these compounds have been identified, among which the most frequent seems to be virucidal activity. Other reported activities are inhibition of virus-entry into the target cells, inhibition of viral protein expression and interference with viral DNA replication, which are all essential processes for generating novel infectious viral particles (Ibáñez et al., 2017).

For botanical extracts in which the active compounds against HSV-1 and HSV-2 have not been purified or identified, their clinical application seems most likely oriented toward topical treatments for cutaneous or mucosal manifestations elicited by these viruses, although some have been shown to be effective if taken orally.

Importantly, botanical drugs derived from botanical extracts and compounds can undergo special health-regulatory 
conditions that favor their progress into the clinic in countries such as the United States, as botanical drugs that are marketed in this country as a dietary supplements may move forward into clinical studies without the need of non-clinical pharmacological/toxicological testing if they have already been proven to have a general recognition of safety (Botanical Drug Development Guidance for Industry, December 2016, Pharmaceutical Quality/CMC). Indeed, some botanical drug products may not require typical Phase 1 tolerability studies if the sponsors can provide adequate justification for the relevance of the prior use in humans and may eventually even be commercialized over-the-counter (OTC). Hence, such indications may significantly help botanical drugs rapidly reach the clinic and help treat both ACV-sensitive and antiviralresistant HSV isolates. Taken together, botanical compounds have the advantage, over other synthetic drugs that they are generally recognized as safe, beneficial and are readily available resources, thus reducing the pricy steps needed for new drug discovery (Pan et al., 2013; Thomford et al., 2018). Furthermore, botanical-based remedies may be lowcost alternatives for unprivileged nations, if the botanicals are available, where access to modern medicine is difficult (Shaikh and Hatcher, 2005; Karunamoorthi et al., 2013). Botanical drugs also have the advantage, over standard small molecule drugs, that they have multiple bioactive compounds that may act synergistically to hamper virus replication, while avoiding antiviral resistance (Yuan et al., 2016; Chugh et al., 2018).

However, botanical drug interactions with other drugs have been reported and undesirable side effects may occur

\section{REFERENCES}

Abu-Jafar, A., and Mahmoud, H. (2017). Antiviral activity of Eucalyptus camaldulensis leaves ethanolic extract on herpes viruses infection. Int. J. Clin. Virol. 1, 001-9.

Akram, M., Tahir, I. M., Shah, S. M. A., Mahmood, Z., Altaf, A., Ahmad, K., et al. (2018). Antiviral potential of medicinal plants against HIV, HSV, influenza, hepatitis, and coxsackievirus: a systematic review. Phyther. Res. 32, 811-822. doi: 10.1002/ptr.6024

Al-Badr, A. A., and Ajarim, T. D. S. (2018). "Ganciclovir," in Profiles of Drug Substances, Excipients and Related Methodology, ed. H. G. Brittain, (Cambridge, MA: Academic Press).

Alboofetileh, M., Rezaei, M., Tabarsa, M., Rittà, M., Donalisio, M., Mariatti, F., et al. (2019). Effect of different non-conventional extraction methods on the antibacterial and antiviral activity of fucoidans extracted from Nizamuddinia zanardinii. Int. J. Biol. Macromol. 124, 131-137. doi: 10.1016/j.ijbiomac.2018. 11.201

Allahverdiyev, A., Duran, N., Ozguven, M., and Koltas, S. (2004). Antiviral activity of the volatile oils of Melissa officinalis L. against Herpes simplex virus type-2. Phytomedicine 11, 657-661. doi: 10.1016/j.phymed.2003.07.014

Amici, C., Rossi, A., Costanzo, A., Ciafrè, S., Marinari, B., Balsamo, M., et al. (2006). Herpes simplex virus disrupts NF- $\mathrm{B}$ regulation by blocking its recruitment on the I $\mathrm{B} \alpha$ promoter and directing the factor on viral genes. J. Biol. Chem. 281, 7110-7117. doi: 10.1074/jbc.m512366200

Arduino, P. G., and Porter, S. R. (2007). Herpes simplex virus type 1 infection: overview on relevant clinico-pathological features. J. Oral. Pathol. Med. 37, 107-121. doi: 10.1111/j.1600-0714.2007.00586.x

Ashley, R. L., Ashley, R. L., Militoni, J., Militoni, J., Lee, F., Lee, F., et al. (1988). Comparison of Western blot and glycoprotein G-specific immunodot
(Tachjian et al., 2010; Ekor, 2014; Lee et al., 2016; Borse et al., 2019). At present, the World Health Organization has developed guidelines to reinforce safety monitoring of botanical medicines using pharmacovigilance systems, as well as encouraging quality controls during production by using modern manufacture techniques and applying good manufacturing practices (WHO, 2000, 2004).

Finally, the expansion of the botanical drug market has attracted significant interest from pharmaceutical companies, which have intensified their development of pre-clinical and pharmacological studies on such drugs forecasting a 6.1\% CAGR growth of approximately 31.6 billion dollars for this field in the period between 2017 and 2022 (Market Watch, 2017). Hence, a steady increase in botanical drugs reaching the market should be expected in the years to come.

\section{AUTHOR CONTRIBUTIONS}

All authors wrote the manuscript, designed the tables, and reviewed the manuscript.

\section{FUNDING}

This work was supported by the Millennium Institute on Immunology and Immunotherapy (P09/016-F), FONDECYT grant \#1190864, the "Fondo de Fomento al Desarrollo Tecnológico" (FONDEF) ID17I10143, and MA Farías is an ANID (CONICYT) fellow \#21191390.

enzyme assay for detecting HSV-1 and HSV-2 antibodies in human sera. J. Clin Microbiol. 26, 662-667. doi: 10.1128/jcm.26.4.662-667.1988

Bacon, T. H., Boon, R. J., Schultz, M., and Hodges-Savola, C. (2002). Surveillance for antiviral-agent-resistant herpes simplex virus in the general population with recurrent herpes labialis. Antimicrob. Agents Chemother. 46, 3042-3044. doi: 10.1128/aac.46.9.3042-3044.2002

Bacon, T. H., Levin, M. J., Leary, J. J., Sarisky, R. T., and Sutton, D. (2003). Herpes simplex virus resistance to acyclovir and penciclovir after two decades of antiviral therapy. Clin. Microbiol. Rev. 16, 114-128. doi: 10.1128/cmr.16.1. 114- 128.2003

Barquero, A. A., Alche, L. E., and Coto, C. E. (1997). Antiviral activity of meliacine on the replication of a thymidine kinase-deficient mutant of Herpes simplex virus type 1 alone and in combination with acyclovir. Int. J. Antimicrob. Agents 9, 49-55. doi: 10.1016/s0924-8579(97)00023-x

Bean, B. (1992). Antiviral therapy: current concepts and practices. Clin. Microbiol. Rev. 5, 146-182. doi: 10.1128/cmr.5.2.146

Bélec, L., Tevi-benissan, C., Bianchi, A., Cotigny, S., Beumont-mauviel, M., Simohamed, A., et al. (2000). In vitro inactivation of Chlamydia trachomatis and of a panel of DNA (HSV-2, CMV, adenovirus, BK virus) and RNA (RSV, enterovirus) viruses by the spermicide benzalkonium chloride. J. Antimicrob. Chemother. 47, 685-693. doi: 10.1093/jac/46.5.685

Belshe, R. B., Leone, P. A., Bernstein, D. I., Wald, A., Levin, M. J., Stapleton, J. T., et al. (2012). Efficacy results of a trial of a herpes simplex vaccine. N. Engl. J. Med. 366, 34-43. doi: 10.1056/NEJMoa1103151

Benedetti, J., Corey, L., and Ashley, R. (1994). Recurrence rates in genital herpes after symptomatic first-episode infection. Ann. Intern. Med. 121, 847-854.

Benzekri, R., Bouslama, L., Papetti, A., Hammami, M., Smaoui, A., and Limam, F. (2018). Anti HSV-2 activity of Peganum harmala (L.) and isolation of the active compound. Microb. Pathog. 114, 291-298. doi: 10.1016/j.micpath.2017.12.017 
Blot, N., Schneider, P., Young, P., Janvresse, C., Dehesdin, D., Tron, P., et al. (2000). Treatment of an acyclovir and foscarnet-resistant herpes simplex virus infection with cidofovir in a child after an unrelated bone marrow transplant. Bone Marrow Transplant. 26, 903-905. doi: 10.1038/sj.bmt.1702591

Borse, S., Singh, D., and Nivsarkar, M. (2019). Understanding the relevance of herb-drug interaction studies with special focus on interplays: a prerequisite for integrative medicine. Porto Biomed. J. 4:e15. doi: 10.1016/j.pbj. 0000000000000015

Boyd, M. R., Safrin, S., and Kern, E. R. (1993). Penciclovir: a review of its spectrum of activity, selectivity, and cross-resistance pattern. Antivir. Chem. Chemother. Suppl. 4, 3-11. doi: 10.1177/095632029300401s01

Brand, Y. M., Roa-Linares, V. C., Betancur-Galvis, L. A., Durán-García, D. C., and Stashenko, E. (2016). Antiviral activity of Colombian Labiatae and Verbenaceae family essential oils and monoterpenes on Human Herpes viruses. J. Essent. Oil Res. 28, 130-137. doi: 10.1080/10412905.2015.1093556

Brezáni, V., Leláková, V., Hassan, S. T. S., Berchová-Bímová, K., Nový, P., Klouček, P., et al. (2018). Anti-infectivity against herpes simplex virus and selected microbes and anti-inflammatory activities of compounds isolated from Eucalyptus globulus labill. Viruses 10:360. doi: 10.3390/v10070360

Bryant, P., Sasadeusz, J., Carapetis, J., Waters, K., and Curtis, N. (2001). Successful treatment of foscarnet-resistant herpes simplex stomatitis with intravenous cidofovir in a child. Pediatr. Infect. Dis. J. 20, 1083-1086. doi: 10.1097/ 00006454-200111000-00016

Buck, C. B., Thompson, C. D., Roberts, J. N., Muller, M., Lowy, D. R., and Schiller, J. T. (2006). Carrageenan is a potent inhibitor of papillomavirus infection. PLoS Pathog. 2:e69. doi: 10.1371/journal.ppat.0020069

Buhles, W. C., Mastre, B. J., Tinker, A. J., Strand, V., and Koretz, S. H. (1988) Ganciclovir treatment of life-or sight-threatening cytomegalovirus infection: experience in 314 immunocompromised patients. Rev. Infect. Dis. 10, S495S506.

Cardozo, F. T., Larsen, I. V., Carballo, E. V., Jose, G., Stern, R. A., Brummel, R. C., et al. (2013). In vivo anti-herpes simplex virus activity of a sulfated derivative of Agaricus brasiliensis mycelial polysaccharide. Antimicrob. Agents Chemother. 57, 2541-2549. doi: 10.1128/AAC.02250-12

Chau, T. (2018). Acyclovir neurotoxicity in a peritoneal dialysis patient: report of a case and review of the pharmacokinetics of acyclovir. Am. J. Case Rep. 19, 1459-1462. doi: 10.12659/ajcr.911520

Chayavichitsilp, P., Buckwalter, J. V., Krakowski, A. C., and Friedlander, S. F. (2009). Herpes simplex. Pediatr. Rev. 30, 119-129. doi: 10.1542/pir.30-4- 119

Chen, F., Xu, H., Liu, J., Cui, Y., Luo, X., Zhou, Y., et al. (2016). Efficacy and safety of nucleoside antiviral drugs for treatment of recurrent herpes labialis: a systematic review and meta-analysis. J. Oral. Pathol. Med. 46, 561-568. doi: 10.1111/jop.12534

Chen, X., Qiao, H., Liu, T., Yang, Z., Xu, L., Xu, Y., et al. (2012). Inhibition of herpes simplex virus infection by oligomeric stilbenoids through ROS generation. Antiviral. Res. 95, 30-36. doi: 10.1016/j.antiviral.2012.05.001

Chen, X., Wang, Z., Yang, Z., Wang, J., Xu, Y., Tan, R., et al. (2011). Houttuynia cordata blocks HSV infection through inhibition of NF- $\kappa \mathrm{B}$ activation. Antiviral. Res. 92, 341-345. doi: 10.1016/j.antiviral.2011.09.005

Chen, Y. C., Sheng, J., Trang, P., and Liu, F. (2018). Potential application of the CRISPR/CAS9 system against herpesvirus infections. Viruses 10, 1-12. doi: 10.3390/v10060291

Chi, C. C., Wang, S. H., Delamere, F. M., Wojnarowska, F., Peters, M. C., and Kanjirath, P. P. (2015). Interventions for prevention of herpes simplex labialis (cold sores on the lips). Cochrane Database Syst. Rev. 8:CD010095. doi: 10.1002/ 14651858.CD010095.pub2

Chilukuri, S., and Rosen, T. (2003). Management of acyclovir-resistant herpes simplex virus. Dermatol Clin. 21, 311-320. doi: 10.1016/s0733-8635(02) 00093-1

Chono, K., Katsumata, K., Kontani, T., Kobayashi, M., Sudo, K., Yokota, T., et al. (2010). ASP2151, a novel helicase-primase inhibitor, possesses antiviral activity against varicella-zoster virus and herpes simplex virus types 1 and 2. J. Antimicrob. Chemother. 65, 1733-1741. doi: 10.1093/jac/ dkq198

Chou, T. Y., and Hong, B. Y. (2014). Ganciclovir ophthalmic gel 0.15\% for the treatment of acute herpetic keratitis: background, effectiveness, tolerability, safety, and future applications. Ther. Clin. Risk. Manag. 10, 665-681. doi: 10.2147/TCRM.S58242
Chugh, N. A., Bali, S., and Koul, A. (2018). Integration of botanicals in contemporary medicine: road blocks, checkpoints and go-ahead signals. Integr. Med. Res. 7, 109-125. doi: 10.1016/j.imr.2018.03.005

Corey, L., Adams, H. G., Brown, Z. A., and Holmes, K. K. (1983). Genital herpes simplex virus infections: clinical manifestations, course, and complications. Ann. Intern. Med. 98, 958-972.

Cowan, F. M., Johnson, A. M., Ashley, R., Corey, L., and Mindel, A. (1994). Antibody to herpes simplex virus type 2 as serological marker of sexual lifestyle in populations. BMJ 309, 1325-1329. doi: 10.1136/bmj.309.6965.1325

Crumpacker, C. S. (1992). Mechanism of action of foscarnet against viral polymerases. Am. J. Med. 92(2 Suppl. 1), 3s-7s.

Damonte, E. B., Pujol, C. A., Mandal, P., Ray, B., and Ghosh, T. (2009). Xylans from Scinaia hatei: structural features, sulfation and anti-HSV activity. Int. J. Biol. Macromol. 46, 173-178. doi: 10.1016/j.ijbiomac.2009.12.003

De Clercq, E. (2013). Selective anti-herpesvirus agents. Antivir. Chem. Chemother. 23, 93-101. doi: 10.3851/IMP2533

De Clercq, E. (2019). Fifty years in search of selective antiviral drugs. J. Med. Chem. 62, 7322-7339. doi: 10.1021/acs.jmedchem.9b00175

De Clercq, E., and Li, G. (2016). Approved antiviral drugs over the past 50 years. Clin. Microbiol. Rev. 29, 695-747. doi: 10.1128/CMR.00102-15

De Sousa Cardozo, F. T. G., Camelini, C. M., Leal, P. C., Kratz, J. M., Nunes, R. J., De Mendonça, M. M., et al. (2014). Antiherpetic mechanism of a sulfated derivative of Agaricus brasiliensis fruiting bodies polysaccharide. Intervirology 57, 375-383. doi: 10.1159/000365194

Deray, G., Martinez, F., Katlama, C., Levaltier, B., Beaufils, H., Danis, M., et al. (1989). Foscarnet nephrotoxicity: mechanism, incidence and prevention. Am. J. Nephrol. 9, 316-321. doi: 10.1159/000167987

Derby, N., Lal, M., Aravantinou, M., Kizima, L., Barnable, P., Rodriguez, A., et al. (2018). Griffithsin carrageenan fast dissolving inserts prevent SHIV HSV-2 and HPV infections in vivo. Nat. Commun. 9:1234567890. doi: 10.1038/s41467-01806349-0

Dinh, T. H., Dunne, E. F., Markowitz, L. E., Weinstock, H., and Berman, S. (2008). Assessing neonatal herpes reporting in the United States, 2000-2005. Sex Transm. Dis. 35, 19-21. doi: 10.1097/olq.0b013e318162c4c6

Doi, Y., Ninomiya, T., Hata, J., Yonemoto, K., Tanizaki, Y., Arima, H., et al. (2009). Seroprevalence of herpes simplex virus 1 and 2 in a population-based cohort in Japan. J. Epidemiol. 19, 56-62. doi: 10.2188/jea.je20080061

Dreno, B., Malkin, J. E., Saiag, P., and Batuji-Garin, S. (2012). Patients' profile, burden of disease and quality of life in recurrent herpes labialis: a survey conducted in USA and France. J. Eur. Acad. Dermatol. Venereol. 26, 1458-1460. doi: 10.1111/j.1468-3083.2011.04348.x

Dvorak, C. C., Cowan, M. J., Horn, B., and Weintrub, P. S. (2009). Development of herpes simplex virus stomatitis during receipt of cidofovir therapy. Clin. Infect. Dis. 49, e92-e95. doi: 10.1086/605678

Ekor, M. (2014). The growing use of herbal medicines: issues relating to adverse reactions and challenges in monitoring safety. Front. Neurol. 4:177. doi: 10.3389/fphar.2013.00177

Emmert, D. H. (2000). Treatment of common cutaneous herpes simplex virus infections. Am. Fam. Phys. 61, 1697-1706.

Eo, S. K., Kim, Y. S., Lee, C. K., and Han, S. S. (2000). Possible mode of antiviral activity of acidic protein bound polysaccharide isolated from Ganoderma lucidum on herpes simplex viruses. J. Ethnopharmacol. 72, 475-481. doi: 10.1016/s0378-8741(00)00266-X

Evans, T. G., Bernstein, D. I., Raborn, G. W., Harmenberg, J., Kowalski, J., and Spruance, S. L. (2000). Double-blind, randomized, placebo-controlled study of topical 5\% acyclovir-1\% hydrocortisone cream (ME-609) for treatment of UV radiation-induced herpes labialis. Antimicrob. Agents Chemother. 46, 1870-1874. doi: 10.1128/aac.46.6.1870-1874.2002

Faith, S. A., Sweet, T. J., Bailey, E., Booth, T., and Docherty, J. J. (2006). Resveratrol suppresses nuclear factor- $\mathrm{B}$ in herpes simplex virus infected cells. Antiviral. Res. 72, 242-251. doi: 10.1016/j.antiviral.2006.06.011

Faral-Tello, P., Mirazo, S., Dutra, C., Perez, A., Geis-Asteggiante, L., Frabasile, S., et al. (2012). Cytotoxic, virucidal, and antiviral activity of South American plant and algae extracts. ScientificWorldJournal 2012:174837. doi: 10.1100/ 2012/174837

Farooq, A. V., and Shukla, D. (2012). Herpes simplex epithelial and stromal keratitis: an epidemiologic update. Surv. Ophthalmol. 57, 448-462. doi: 10.1016/ j.survophthal.2012.01.005 
Fatahzadeh, M., and Schwartz, R. A. (2007). Human herpes simplex virus infections: epidemiology, pathogenesis, symptomatology, diagnosis, and management. J. Am. Acad. Dermatol. 57, 736-737.

Field, H. J. (2001). Herpes simplex virus antiviral drug resistance - Current trends and future prospects. J. Clin. Virol. 21, 261-269. doi: 10.1016/s1386-6532(00) 00169-4

Fleming, D. T., McQuillan, G. M., Johnson, R. E., Nahmias, A. J., Aral, S. O., Lee, F. K., et al. (1997). Herpes simplex virus type 2 in the United States, 1976 to 1994. N. Engl. J. Med. 337, 1105-1111.

Ganjhu, R. K., Mudgal, P. P., Maity, H., Dowarha, D., Devadiga, S., Nag, S., et al. (2015). Herbal plants and plant preparations as remedial approach for viral diseases. VirusDisease 26, 225-236. doi: 10.1007/s13337-015-0276-6

Garozzo, A., Timpanaro, R., Bisignano, B., Furneri, P. M., Bisignano, G., and Castro, A. (2009). In vitro antiviral activity of Melaleuca alternifolia essential oil. Lett. Appl. Microbiol. 49, 806-808. doi: 10.1111/j.1472-765X.2009. 02740.x

Gerber, P., Dutcher, J. D., Adams, E. V., and Sherman, J. H. (1958). Protective effect of seaweed extracts for chicken embryos infected with influenza B or mumps virus. Proc. Soc. Exp. Biol. Med. 99, 590-593. doi: 10.3181/00379727-9924429

Gnann, J. W., Barton, N. H., and Whitley, R. J. (1983). Acyclovir: mechanism of action, pharmacokinetics, safety and clinical applications. Pharmacother. J. Hum. Pharmacol. Drug. Ther. 3, 275-283. doi: 10.1002/j.1875-9114.1983. tb03274.x

Godfrey, H. R., Godfrey, N. J., Godfrey, J. C., and Riley, D. (2001). A randomized clinical trial on the treatment of oral herpes with topical zinc oxide/glycine. Altern. Ther. Heal. Med. 7, 49-56.

Gu, C. Q., Li, J. W., Chao, F., Jin, M., Wang, X. W., and Shen, Z. Q. (2007) Isolation, identification and function of a novel anti-HSV-1 protein from Grifola frondosa. Antiviral. Res. 75, 250-257. doi: 10.1016/j.antiviral.2007. 03.011

Hammer, K. D. P., Dietz, J., Lo, T. S., and Johnson, E. M. (2018). A systematic review on the efficacy of topical acyclovir, penciclovir, and docosanol for the treatment of herpes simplex labialis. EMJ Dermatol. 6, 118-123.

Handel, S., Klingler, E. J., Washburn, K., Blank, S., and Schillinger, J. A. (2011). Population-based surveillance for neonatal herpes in New York City. April 2006-September 2010. Sex. Transm. Dis. 38, 705-711.

Hassan, S. T. S., Masarćíková, R., and Berchová, K. (2015). Bioactive natural products with anti-herpes simplex virus properties. J. Pharm. Pharmacol. 67, 1325-1336. doi: 10.1111/jphp.12436

Hayashi, K., Nakano, T., Hashimoto, M., Kanekiyo, K., and Hayashi, T. (2008). Defensive effects of a fucoidan from brown alga Undaria pinnatifida against herpes simplex virus infection. Int. Immunopharmacol. 8, 109-116. doi: 10.1016/j.intimp.2007.10.017

Ho, H.-T., Woods, K. L., De Boeck, H., Bronson, J. J., Martin, J. C., and Hitchcock, M. J. M. (1991). Intracellular metabolism of the antiherpes agent (S)1-[3-hydroxy-2-(phosphonylmethoxy)propyl]cytosine. Mol. Pharmacol. 41, $197-202$.

Hodge, R. A. V., and Perkins, R. M. (1989). Mode of action of 9-(4-hydroxy-3hydroxyemthylbut-1-yl)guanine (BRL 39123) against herpes simplex virus in MRC-5 cells. Antimicrob. Agents Chemother. 33, 223-229. doi: 10.1128/aac.33. 2.223

Hodge, R. A. V., Sutton, D., Boyd, M. R., Harnden, M. R., and Jarvest, R. L. (1989). Selection of an oral prodrug (BRL 42810; famciclovir) for the antiherpesvirus agent BRL 39123 [9-(4-hydroxy-3-hydroxymethylbut-1yl)guanine; penciclovir]. Antimicrob. Agents Chemother. 33, 1765-1773. doi: 10.1128/aac.33.10.1765

Hostetler, K. Y. (2009). Alkoxyalkyl prodrugs of acyclic nucleoside phosphonates enhance oral antiviral activity and reduce toxicity: current state of the art. Antiviral Res. 82, 84-98.

Huang, Z., Nong, X., Ren, Z., Wang, J., Zhang, X., and Qi, S. (2017). AntiHSV-1, antioxidant and antifouling phenolic compounds from the deep-seaderived fungus Aspergillus versicolor SCSIO 41502. Bioorg. Med. Chem. Lett. 27, 787-791. doi: 10.1016/j.bmcl.2017.01.032

Hung, P. Y., Ho, B. C., Lee, S. Y., Chang, S. Y., Kao, C. L., Lee, S. S., et al. (2015). Houttuynia cordata targets the beginning stage of herpes simplex virus infection. PLoS One 10:e0115475. doi: 10.1371/journal.pone.011 5475
Ibáñez, F. J., Farías, M. A., Gonzalez-Troncoso, M. P., Corrales, N., Duarte, L. F., Retamal-Díaz, A., et al. (2018). Experimental dissection of the lytic replication cycles of herpes simplex viruses in vitro. Front. Microbiol. 9:2406. doi: 10.3389/ fmicb.2018.02406

Ibáñez, F. J., Farías, M. A., Retamal-díaz, A., and Espinoza, J. A. (2017). Pharmacological induction of heme oxygenase-1 impairs nuclear accumulation of herpes simplex virus capsids upon infection. Front. Microbiol. 8:2108. doi: 10.3389/fmicb.2017.02108

Jadhav, P., Kapoor, N., Thomas, B., Lal, H., and Kshirsagar, N. (2012). Antiviral potential of selected indian medicinal (Ayurvedic) plants against herpes simplex virus 1 and 2. N. Am. J. Med. Sci. 4, 641-647.

James, S. H., and Prichard, M. N. (2014). Current and future therapies for herpes simplex virus infections: mechanism of action and drug resistance. Curr. Opin. Virol. 8, 54-61. doi: 10.1016/j.coviro.2014.06.003

Javaly, K., Wohlfeiler, M., Kalayjian, R., Klein, T., Bryson, Y., Grafford, K., et al. (1999). Treatment of mucocutaneous herpes simplex virus infections unresponsive to acyclovir with topical foscarnet cream in AIDS patients: a phase I/II study. J. Acquir. Immune Defic. Syndr. 21, 301-306.

Jiang, Y. C., Feng, H., Lin, Y. C., and Guo, X. R. (2016). New strategies against drug resistance to herpes simplex virus. Int. J. Oral. Sci. 8, 1-6. doi: 10.1038/ijos.2016.3

Jin, F., Zhuo, C., He, Z., Wang, H., Liu, W., Zhang, R., et al. (2015). Anti-herpes simplex virus activity of polysaccharides from Eucheuma gelatinae. World J. Microbiol. Biotechnol. 31, 453-460. doi: 10.1007/s11274-015-1798-1

Johnston, C., and Corey, L. (2015). Current concepts for genital herpes simplex virus infection: diagnostics and pathogenesis of genital tract shedding. Clin. Microbiol. Rev. 29, 149-161. doi: 10.1128/CMR.00043-15

Kalu, N. N., Desai, P. J., Shirley, C. M., Gibson, W., Dennis, P. A., and Ambinder, R. F. (2014). Nelfinavir inhibits maturation and export of herpes simplex virus 1. J. Virol. 88, 5455-5461. doi: 10.1128/JVI.03790-13

Karunamoorthi, K., Jegajeevanram, K., Vijayalakshmi, J., and Mengistie, E. (2013). Traditional medicinal plants: a source of phytotherapeutic modality in resource-constrained health care settings. J. Evid. Based Compl. Altern. Med. 18 , 67-74. doi: $10.1177 / 2156587212460241$

Kaur, J., Kaur, S., and Mahajan, A. (2013). Herbal medicines: possible risks and benefits. Am. J. Phytomed. Clin. Ther. 141104, 226-239.

Kawashima, M., Nemoto, O., Honda, M., Watanabe, D., Nakayama, J., Imafuku, S., et al. (2017). Amenamevir, a novel helicase-primase inhibitor, for treatment of herpes zoster: a randomized, double-blind, valaciclovir-controlled phase 3 study. J. Dermatol. 44, 1219-1227. doi: 10.1111/1346-8138.13948

Kaye, S., and Choudhary, A. (2006). Herpes simplex keratitis. Prog. Retin. Eye Res. $25,355-380$.

Kimberlin, D. W., and Whitley, R. J. (2007). “Antiviral therapy of HSV-1 and -2," in Human Herpesviruses: Biology, Therapy, and Immunoprophylaxis, eds A. Arvin, G. Campadelli-Fiume, E. Mocarski, P. S. Moore, B. Roizman, R. Whitley, et al. (Cambridge: Cambridge University).

Kinchington, P. R., Leger, A. J. S., Guedon, J.-M. G., and Hendricks, R. L. (2012). Herpes simplex virus and varicella zoster virus, the house guests who never leave. Herpesviridae 3:5. doi: 10.1186/2042-4280-3-5

Kleymann, G., Fischer, R., Betz, U. A. K., Hendrix, M., Bender, W., Schneider, U., et al. (2002). New helicase-primase inhibitors as drug candidates for the treatment of herpes simplex disease. Nat. Med. 8, 392-398. doi: 10.1038/ nm0402-392

Kroon, S. (1990). Genital herpes-when and how to treat. Semin. Dermatol. 9, 133-140.

Kukhanova, M. K., Korovina, A. N., and Kochetkov, S. N. (2014). Human herpes simplex virus: life cycle and development of inhibitors. Biochemistry 79, 1635-1652. doi: 10.1134/S0006297914130124

Kurokawa, M., Nagasaka, K., Hirabayashi, T., Uyama, S., Sato, H., Kageyama, T., et al. (1995). Efficacy of traditional herbal medicines in combination with acyclovir against herpes simplex virus type 1 infection in vitro and in vivo. Antivir. Res. 27, 19-37. doi: 10.1016/0166-3542(94)00076-k

Kwant, A., and Rosenthal, K. L. (2004). Intravaginal immunization with viral subunit protein plus $\mathrm{CpG}$ oligodeoxynucleotides induces protective immunity against HSV-2. Vaccine 22, 3098-3104. doi: 10.1016/j.vaccine.2004.01.059

Lafferty, W. E., Coombs, R. W., Benedetti, J., Critchlow, C., and Corey, L. (1987). Recurrences after oral and genital herpes simplex virus infection. Influence of 
site of infection and viral type. N. Engl. J. Med. 316, 1444-1449. doi: 10.1056/ nejm 198706043162304

Lea, A. P., and Bryson, H. M. (1996). Cidofovir. Drugs 52, 225-230. doi: 10.2165/ 00003495-199652020-00006

Lebrun-Vignes, B., Bouzamondo, A., Dupuy, A., Guillaume, J. C., Lechat, P., and Chosidow, O. (2007). A meta-analysis to assess the efficacy of oral antiviral treatment to prevent genital herpes outbreaks. J. Am. Acad. Dermatol. 57, 238-246. doi: 10.1016/j.jaad.2007.02.008

Lee, C. K., Kim, H. S., Nam, J. R., Lee, M. J., Yim, J. H., Lee, H. K., et al. (2009). AntiPicornavirus activity and other antiviral activity of sulfated exopolysaccharide from the marine microalga gyrodinium impudicum strain KG03. Antiviral. Res. 82, A40-A40.

Lee, E., Pavy, M., Young, N., Freeman, C., and Lobigs, M. (2006). Antiviral effect of the heparan sulfate mimetic, PI-88, against dengue and encephalitic flaviviruses. Antiviral. Res. 69, 31-38. doi: 10.1016/j.antiviral.2005.08.006

Lee, J. B., Hayashi, K., Hayashi, T., Sankawa, U., and Maeda, M. (1999). Antiviral activities against HSV-1, HCMV, and HIV-1 of rhamnan sulfate from Monostroma latissimum. Planta Med. 65, 439-441. doi: 10.1055/s-2006-960804

Lee, J. L., Ayashi, K. H., Ashimoto, M. H., Akano, T. N., and Ayashi, T. H. (2004) Novel antiviral fucoidan from sporophyll of Undaria pinnatifida (Mekabu). Chem. Pharm. Bull. 52, 1091-1094. doi: 10.1248/cpb.52.1091

Lee, J. Y., Jun, S. A., Hong, S. S., Ahn, Y. C., Lee, D. S., and Son, C. G. (2016) Systematic review of adverse effects from herbal drugs reported in randomized controlled trials. Phyther. Res. 1419, 1412-1419. doi: 10.1002/ptr.5647

Lee, Y. J., Neofytos, D., Kim, S. J., Cheteyan, L., Huang, Y. T., Papadopoulos, E. B., et al. (2018). Efficacy of brincidofovir as prophylaxis against HSV and VZV in hematopoietic cell transplant recipients. Transpl. Infect. Dis. 20, e12977. doi: $10.1111 /$ tid.12977

Leflore, S., Anderson, P. L., and Fletcher, C. V. (2000). A risk-benefit evaluation of aciclovir for the treatment and prophylaxis of herpes simplex virus infections. Drug Saf. 23, 131-142. doi: 10.2165/00002018-200023020-00004

Levendosky, K., Mizenina, O., Martinelli, E., Jean-Pierre, N., Kizima, L., Rodriguez, A., et al. (2015). Griffithsin and carrageenan combination to target herpes simplex virus 2 and human papillomavirus. Antimicrob. Agents Chemother. 59, 7290-7298. doi: 10.1128/AAC.01816-15

Leyton, L., Hott, M., Acuña, F., Caroca, J., Nuñez, M., Martin, C., et al. (2015). Nutraceutical activators of AMPK/Sirtl axis inhibit viral production and protect neurons from neurodegenerative events triggered during HSV-1 infection. Virus Res. 205, 63-72. doi: 10.1016/j.virusres.2015.05.015

Li, T., Liu, L., Wu, H., Chen, S., Zhu, Q., Gao, H., et al. (2017). Anti-herpes simplex virus type 1 activity of Houttuynoid A, a flavonoid from Houttuynia cordata Thunb. Antiviral. Res. 144, 273-280. doi: 10.1016/j.antiviral.2017.06.010

Li, W., Wang, X. H., Luo, Z., Liu, L. F., Yan, C., Yan, C. Y., et al. (2018). Traditional chinese medicine as a potential source for hsv-1 therapy by acting on virus or the susceptibility of host. Int. J. Mol. Sci. 19, 1-23.

Liang, T. M., Fang, Y. W., Zheng, J. Y., and Shao, C. L. (2018). Secondary metabolites isolated from the gorgonian-derived fungus Aspergillus ruber and their antiviral activity. Chem. Nat. Compd. 54, 559-561. doi: 10.1007/s10600018-2406-z

Lipipun, V., Kurokawa, M., Suttisri, R., Taweechotipatr, P., Pramyothin, P., Hattori, M., et al. (2003). Efficacy of Thai medicinal plant extracts against herpes simplex virus type 1 infection in vitro and in vivo. Antiviral. Res. 60, 175-180. doi: 10.1016/s0166-3542(03)00152-9

Lolis, M. S., Gonzalez, L., Cohen, P. J., and Schwartz, R. A. (2016). Drug-resistant herpes simplex virus in HIV infected patients. Acta Dermatovenerol. Croat. 16, 204-208.

Looker, K. J., Garnett, G. P., and Schmid, G. P. (2008). An estimate of the global prevalence and incidence of herpes simplex virus type 2 infection. Bull. World Heal. Organ. 86, 805-812. doi: 10.2471/blt.07.046128

Lopes, N., Ray, S., Espada, S. F., Bomfim, W. A., Ray, B., Faccin-Galhardi, L. C., et al. (2017). Green seaweed Enteromorpha compressa (Chlorophyta, Ulvaceae) derived sulphated polysaccharides inhibit herpes simplex virus. Int. J. Biol. Macromol. 102, 605-612. doi: 10.1016/j.ijbiomac.2017.04.043

Luber, A. D., and Flaherty, J. F. (1996). Famciclovir for treatment of herpesvirus infections. Ann. Pharmacother. 30, 978-985. doi: 10.1177/ 106002809603000913

Ma, F., Shen, W., Zhang, X., Li, M., Wang, Y., Zou, Y., et al. (2016). AntiHSV activity of Kuwanon $\mathrm{X}$ from mulberry leaves with genes expression inhibitory and HSV-1 induced NF-кB deactivated properties. Biol. Pharm. Bull. 39, 1667-1674. doi: 10.1248/bpb.b16-00401

Mahmoud, H. (2017). Antiviral activity of Eucalyptus camaldulensis leaves ethanolic extract on herpes viruses infection. Int. J. Clin. Virol. 1, 001-009. doi: 10.29328/journal.ijcv.1001001

Market Watch (2017). Market will Grow from \$29.4 Billion in 2017 to Approx. \$39.6 Billion by 2022 with a CAGR of $6.1 \%$. Available at: www.marketwatch.com (accessed December 27, 2019).

Markham, A., and Faulds, D. (1994). Ganciclovir. An update of its therapeutic use in cytomegalovirus infection. Drugs 48, 455-484. doi: 10.2165/00003495199448030-00009

Markowitz, M., Conant, M., Hurley, A., Schluger, R., Duran, M., Peterkin, J., et al. (1998). A preliminary evaluation of nelfinavir mesylate, an inhibitor of human immunodeficiency virus (HIV)-1 Protease, to treat HIV infection. J. Infect. Dis. 177, 1533-1540. doi: 10.1086/515312

Matthews, T., and Boehme, R. (1988). Antiviral activity and mechanism of action of ganciclovir. Rev. Infect. Dis. 10, S490-S494.

Mazzanti, G., Battinelli, L., Pompeo, C., Serrilli, A. M., Rossi, R., Sauzullo, I. et al. (2008). Inhibitory activity of Melissa officinalis L. extract on Herpes simplex virus type 2 replication. Nat. Prod. Res. 22, 1433-1440. doi: 10.1080/ 14786410802075939

McCarthy, J. P., Browning, W. D., Teerlink, C., and Veit, G. (2012). Treatment of herpes labialis: comparison of two OTC drugs and untreated controls. J. Esthet. Restor. Dent. 24, 103-109. doi: 10.1111/j.1708-8240.2011. 00417.x

McGeoch, D. J. (2009). Lineages of varicella-zoster virus. J. Gen. Virol. 90, 963-969. doi: 10.1099/vir.0.007658-0

Meira, R. Z. C., Biscaia, I. F. B., Nogueira, C., Murakami, F. S., Bernardi, L. S., and Oliveira, P. R. (2019). Solid-state characterization and compatibility studies of penciclovir, lysine hydrochloride, and pharmaceutical excipients. Materials 12, E3154. doi: 10.3390/ma12193154

Mendes, S., Bravin, I. C., Yokoya, N. S., and Villela, M. T. (2012). AntiHSV activity of Hypnea musciformis cultured with different phytohormones. Rev. Bras. Farmacogn. 22, 789-794. doi: 10.1590/s0102-695x201200500 0054

Mertz, G. J., Benedetti, J., Ashley, R., Selke, S. A., and Corey, L. (1992). Risk factors for the sexual transmission of genital herpes. Ann. Intern. Med. 116, 197-202.

Mertz, K. J., Trees, D., Levine, W. C., Lewis, J. S., Litchfield, B., Pettus, K. S., et al. (1998). Etiology of genital ulcers and prevalence of human immunodeficiency virus coinfection in 10 US cities. The genital ulcer disease surveillance group. J. Infect. Dis. 178, 1795-1798. doi: 10.1086/314502

Mindel, A. (1991). Is it meaningful to treat patients with recurrent herpetic infections? Scand. J. Infect. Dis. Suppl. 80, 27-32.

Mondal, D. (2007). Famciclovir. xPharm: The Comprehensive Pharmacology Reference. Amsterdam: Elsevier, 1-4. doi: 10.1016/B978-008055232-3.61737-4

Moomaw, M. D., Cornea, P., Rathbun, R. C., and Wendel, K. A. (2003). Review of antiviral therapy for herpes labialis, genital herpes and herpes zoster. Expert. Rev. Anti Infect. Ther. 1, 283-295. doi: 10.1586/14787210. 1.2.283

Morfin, F., and Thouvenot, D. (2003). Herpes simplex virus resistance to antiviral drugs. J. Clin. Virol. 26, 29-37. doi: 10.1016/s1386-6532(02)00 263-9

Nixon, B., Stefanidou, M., Mesquita, P. M. M., Fakioglu, E., Segarra, T., Rohan, L., et al. (2013). Griffithsin protects mice from genital herpes by preventing cell-to-cell spread. J. Virol. 87, 6257-6269. doi: 10.1128/JVI.00012-13

Okba, M. M., El Gedaily, R. A., and Ashour, R. M. (2017). UPLC-PDA-ESIqTOF-MS profiling and potent anti-HSV-II activity of Eucalyptus sideroxylon leaves. J. Chromatogr. B Anal. Technol. Biomed. Life Sci. 106, 335-342. doi: 10.1016/j.jchromb.2017.10.065

Ormrod, D., Scott, L. J., and Perry, C. M. (2000). Valaciclovir: a review of its long term utility in the management of genital herpes simplex virus and cytomegalovirus infections. Drugs 59, 839-863. doi: 10.2165/00003495200059040-00013

Pacheco, P., Sierra, J., Schmeda-Hirschman, G., Potter, C. W., Jones, B. M., Moshref, M., et al. (1993). Antiviral activity of chilean medicinal plant extracts. Phyther. Res. 7, 415-418. doi: 10.1002/ptr.2650070606

Pan, S. Y., Zhou, S. F., Gao, S. H., Yu, Z. L., Zhang, S. F., Tang, M. K., et al. (2013). New perspectives on how to discover drugs from herbal medicines: CAM'S 
outstanding contribution to modern therapeutics. Evid. Based Compl. Altern. Med. 2013:627375.

Park, H., Kurokawa, M., Shiraki, K., Nakaruma, N., Choi, J., and Hattori, M. (2014). Antiviral activity of the marine alga Symphyocladia latiuscula against Herpes simplex virus (HSV-1) in vitro and its therapeutic efficacy against HSV-1 Infection in Mice. Biol. Pharm. Bull. 28, 2258-2262. doi: 10.1248/bpb.28.2258

Patick, A. K., Mo, H., Markowitz, M., Appelt, K., Wu, B., Musick, L., et al. (1996). Antiviral and resistance studies of AG1343, an orally bioavailable inhibitor of human immunodeficiency virus protease. Antimicrob. Agents Chemother. 40, 292-297. doi: 10.1128/aac.40.2.292

Paz-Bailey, G., Ramaswamy, M., Hawkes, S. J., and Geretti, A. M. (2008). Herpes simplex virus type 2: epidemiology and management options in developing countries. Postgrad. Med. J. 84, 299-306. doi: 10.1136/sti.2006.020966

Perna, J. J., Mannix, M. L., Rooney, J. F., Notkins, A. L., and Straus, S. E. (1987). Reactivation of latent herpes simplex virus infection by ultraviolet light: a human model. J. Am. Acad. Dermatol. 17, 473-478. doi: 10.1016/s01909622(87)70232-1

Petrera, E., and Coto, C. E. (2009). Therapeutic effect of meliacine, an antiviral derived from Melia azedarach L., in mice genital herpetic infection. Phytother Res. 23, 1771-1777. doi: 10.1002/ptr.2850

Poole, C. L., and James, S. H. (2018). Antiviral therapies for herpesviruses: current agents and new directions. Clin. Ther. 40, 1282-1298. doi: 10.1016/j.clinthera. 2018.07.006

Pope, L. E., Marcelletti, J. F., Katz, L. R., Lin, J. Y., Katz, D. H., Parish, M. L., et al. (1998). The anti-herpes simplex virus activity of $n$-docosanol includes inhibition of the viral entry process. Antivir. Res. 40, 85-94. doi: 10.1016/s01663542(98)00048-5

Pradeep, P., Manju, V., and Ahsan, M. F. (2019). "Antiviral potency of mushroom constituents," in Medicinal Mushrooms, eds D. Agrawal, and M. Dhanasekaran, (Singapore: Springer), 275-297. doi: 10.1007/978-981-13-6382-5_10

Prichard, M. N., Kern, E. R., Hartline, C. B., Lanier, E. R., and Quenelle, D. C. (2011). CMX001 potentiates the efficacy of acyclovir in herpes simplex virus infections. Antimicrob. Agents Chemother. 55, 4728-4734. doi: 10.1128/AAC. 00545-11

Pujol, C. A., Ray, S., Ray, B., and Damonte, E. B. (2012). Antiviral activity against dengue virus of diverse classes of algal sulfated polysaccharides. Int. J. Biol. Macromol. 51, 412-416. doi: 10.1016/j.ijbiomac.2012. 05.028

Quenelle, D. C., Lampert, B., Collins, D. J., Rice, T. L., Painter, G. R., and Kern, E. R. (2010). Efficacy of CMX001 against herpes simplex virus infections in mice and correlations with drug distribution studies. J. Infect. Dis. 202, 1492-1499. doi: $10.1086 / 656717$

Ramchandani, M., Kong, M., Tronstein, E., Selke, S., Mikhaylova, A., Magaret, A., et al. (2017). Oral mucosa of healthy adults. Sex. Trans. Dis. 43, 756-760.

Rand, K. H., Hoon, E. F., Massey, J. K., and Johnson, J. H. (1990). Daily stress and recurrence of genital herpes simplex. Arch. Intern. Med. 150, 1889-1893. doi: 10.1001/archinte.150.9.1889

Rattanathongkom, A., Lee, J.-B., Hayashi, K., Sripanidkulchai, B.-O., Kanchanapoom, T., and Hayashi, T. (2009). Evaluation of Chikusetsusaponin IVa isolated from Alternanthera philoxeroides for its potency against viral replication. Planta Med. 75, 829-835. doi: 10.1055/s-0029-1185436

Reusser, P. (1996). Herpesvirus resistance to antiviral drugs: a review of the mechanisms, clinical importance and therapeutic options. J. Hosp. Infect. 33, 235-248. doi: 10.1016/s0195-6701(96)90010-9

Ribeiro, M., Robaina, M., Mendes, G., Silva, T., Gestinari, L., Pamplona, O., et al. (2012). Antiviral activity of extracts from Brazilian seaweeds against herpes simplex virus. Rev. Bras. Farmacogn. 22, 714-723. doi: 10.3390/ molecules 18055761

Roner, M. R., Sprayberry, J., Spinks, M., and Dhanji, S. (2007). Antiviral activity obtained from aqueous extracts of the Chilean soapbark tree (Quillaja saponaria Molina). J. Gen. Virol. 88, 275-285. doi: 10.1099/vir.0.82 321-0

Roozbahani, M., and Hammersmith, K. M. (2018). Management of herpes simplex virus epithelial keratitis. Curr. Opin. Ophthalmol. 29, 360-364. doi: 10.1097/ ICU.0000000000000483

Rowley, D. C., Kelly, S., Kauffman, C. A., Jensen, P. R., and Fenical, W. (2003) Halovirs A-E, new antiviral agents from a marine-derived fungus of the genus Scytalidium. Bioorgan. Med. Chem. 11, 4263-4274. doi: 10.1016/s09680896(03)00395- $x$

Sacks, S. L., Thisted, R. A., Jones, T. M., Barbarash, R. A., Mikolich, D. J., Ruoff, G. E., et al. (2001). Clinical efficacy of topical docosanol $10 \%$ cream for herpes simplex labialis: a multicenter, randomized, placebo-controlled trial. J. Am. Acad. Dermatol. 45, 222-230. doi: 10.1067/mjd.2001.116215

Santoyo, S., Jaime, L., Plaza, M., Herrero, M., Rodriguez-Meizoso, I., Ibanez, E., et al. (2012). Antiviral compounds obtained from microalgae commonly used as carotenoid sources. J. Appl. Phycol. 24, 731-741. doi: 10.1007/s10811-0119692-1

Sarisky, R. T., Bacon, T., Boon, R., Locke, L., Nguyen, T. T., Leary, J., et al. (2002). Penciclovir susceptibilities of herpes simplex virus isolates from patients using penciclovir cream for treatment of recurrent herpes labialis. Antimicrob. Agents Chemother. 46, 2848-2853. doi: 10.1128/aac.46.9.2848-2853.2002

Sarisky, R. T., Bacon, T. H., Boon, R. J., Duffy, K. E., Esser, K. M., Leary, J., et al. (2003). Profiling penciclovir susceptibility and prevalence of resistance of herpes simplex virus isolates across eleven clinical trials. Arch. Virol. 148, 1757-1769. doi: 10.1007/s00705-003-0124-7

Sauerbrei, A. (2016). Optimal management of genital herpes: current perspectives. Infect. Drug Resist. 9, 129-141. doi: 10.2147/IDR.S96164

Schillinger, J. A., Xu, F., Sternberg, M. R., Armstrong, G. L., Lee, F. K., Nahmias, A. J., et al. (2004). National seroprevalence and trends in herpes simplex virus type 1 in the United States, 1976-1994. Sex Transm. Dis. 31, 753-760. doi: 10.1097/01.olq.0000145852.43262.c3

Schnitzler, P., Schön, K., and Reichling, J. (2001). Antiviral activity of Australian tea tree oil and eucalyptus oil against herpes simplex virus in cell culture. Pharmazie $56,343-347$.

Schuster, A. K., Harder, B. C., Schlichtenbrede, F. C., Jarczok, M. N., and Tesarz, J. (2016). Valacyclovir versus acyclovir for the treatment of herpes zoster ophthalmicus in immunocompetent patients. Cochrane Database Syst. Rev. 1:CD011503.

Sebei, K., Sakouhi, F., Herchi, W., Khouja, M. L., and Boukhchina, S. (2015). Chemical composition and antibacterial activities of seven Eucalyptus species essential oils leaves. Biol. Res. 48, 1-5.

Semprini, A., Singer, J., Braithwaite, I., Shortt, N., Thayabaran, D., McConnell, M., et al. (2019). Kanuka honey versus aciclovir for the topical treatment of herpes simplex labialis: a randomised controlled trial. BMJ Open 9:e026201. doi: 10.1136/bmjopen-2018-026201

Shaikh, B. T., and Hatcher, J. (2005). Complementary and alternative medicine in Pakistan: prospects and limitations. Evid. Based Compl. Altern. Med. 2, 139-142. doi: $10.1093 /$ ecam/neh088

Simpson, D., and Lyseng-Williamson, K. A. (2006). Famciclovir- review of its use in herpes zoster and genital and orolabial herpes. Drugs 66, 2397-2416. doi: 10.2165/00003495-200666180-00016

Smee, D., Martin, J., Verheyden, J., and Matthews, T. (1983). Anti-Herpesvirus activity of the acyclic nucleoside 9-(1,3-Dihydroxy-2-Propoxymethyl)Guanine. Antimicrob. Agents Chemother. 23, 676-682. doi: 10.1128/aac.23.5.676

Smith, J. S., and Robinson, N. J. (2002). Age-specific prevalence of infection with herpes simplex virus types 2 and 1: a global review. J. Infect. Dis. 186, S3-S28.

Soul-Lawton, J., Seaber, E., On, N., Wootton, R., Rolan, P., and Posner, J. (1995). Absolute bioavailability and metabolic disposition of valaciclovir, the L- valyl ester of acyclovir, following oral administration to humans. Antimicrob. Agents Chemother. 39, 2759-2764. doi: 10.1128/aac.39.12.2759

Souza, L. M., De Sassaki, G. L., Teresa, M., and Romanos, V. (2012). Structural characterization and Anti-HSV-1 and HSV-2 activity of glycolipids from the marine algae Osmundaria obtusiloba isolated from Southeastern Brazilian coast. Mar. Drugs. 10, 918-931. doi: 10.3390/md10040918

Souza, T. M. L., Abrantes, J. L., Epifanio, R. D. A., Fontes, C. F. L., and Frugulhetti, I. C. P. P. (2007). The alkaloid 4-methylaaptamine isolated from the sponge Aaptos aaptos impairs Herpes simplex virus type 1 penetration and immediateearly protein synthesis. Planta Med. 73, 200-205. doi: 10.1055/s-2007967109

Spruance, S. L. (1993). Prophylactic chemotherapy with acyclovir for recurrent herpes simplex labialis. J. Med. Virol. 41(1 Suppl), 27-32. doi: 10.1002/jmv. 1890410507

Spruance, S. L., Overall, J. C. Jr., Kern, E. R., Krueger, G. G., Pliam, V., et al. (1977). The natural history of recurrent herpes simplex labialis: 
implications for antiviral therapy. N. Engl. J. Med. 297, 69-75. doi: 10.1056/ nejm 197707142970201

Spruance, S. L., Stewart, J. C., Rowe, N. H., McKeough, M. B., Wenerstrom, G., and Freeman, D. J. (1990). Treatment of recurrent herpes simplex labialis with oral acyclovir. J. Infect. Dis. 161, 185-190.

Stevens, J. G., and Cook, M. L. (1971). Latent herpes simplex virus in spinal ganglia of mice. Science 173, 843-845. doi: 10.1126/science.173.3999.843

Strand, A., Böttiger, D., Gever, L. N., and Wheeler, W. (2012). Safety and tolerability of combination acyclovir 5\% and hydrocortisone $1 \%$ cream in adolescents with recurrent herpes simplex labialis. Pediatr. Dermatol. 29, 105-110. doi: 10.1111/ j.1525-1470.2011.01570.x

Stranska, R., Schuurman, R., Nienhuis, E., Goedegebuure, I. W., Polman, M., Weel, J. F., et al. (2005). Survey of acyclovir-resistant herpes simplex virus in the Netherlands: prevalence and characterization. J. Clin. Virol. 32, 7-18. doi: $10.1016 /$ j.jcv.2004.04.002

Suazo, P. A., Tognarelli, E. I., Kalergis, A. M., and González, P. A. (2014). Herpes simplex virus 2 infection: molecular association with HIV and novel microbicides to prevent disease. Med. Microbiol. Immunol. 204, 161-176. doi: 10.1007/s00430-014-0358-x

Sun, Q. L., Li, Y., Ni, L. Q., Li, Y. X., Cui, Y. S., Jiang, S. L., et al. (2019). Structural characterization and antiviral activity of two fucoidans from the brown algae Sargassum henslowianum. Carbohydr. Polym. 229:115487. doi: 10.1016/j.carbpol.2019

Tachjian, A., Maria, V., and Jahangir, A. (2010). Use of Herbal Products and Potential Interactions in Patients With Cardiovascular Diseases. J. Am. Coll. Cardiol. 55, 515-525. doi: 10.1016/j.jacc.2009.07.074

Taylor-Robinson, D., and Ballard, R. C. (2001). In vitro inactivation of Chlamydia trachomatis and of a panel of DNA (HSV-2, CMV, adenovirus, BK virus) and RNA (RSV, enterovirus) viruses by the spermicide benzalkonium chloride. J. Antimicrob. Chemother. 46, 685-693. doi: 10.1093/jac/46.5.685

Thin, R. N., Nabarro, J. M., Parker, J. D., and Fiddian, A. P. (1983). Topical acyclovir in the treatment of initial genital herpes. Sex Transm. Infect. 59, 116-119. doi: 10.1136/sti.59.2.116

Thomford, N. E., Senthebane, D. A., Rowe, A., Munro, D., Seele, P., Maroyi, A., et al. (2018). Natural products for drug discovery in the 21 st century: innovations for novel drug discovery. Int. J. Mol. Sci. 19:E1578. doi: 10.3390/ ijms 19061578

Thuy, T. T., Ly, B. M., Van, T. T., Quang, N. V., Tu, H. C., Zheng, Y., et al. (2015). Anti-HIV activity of fucoidans from three brown seaweed species. Carbohydr. Polym. 115, 122-128. doi: 10.1016/j.carbpol.2014. 08.068

Treister, N. S., and Woo, S. B. (2010). Topical n-docosanol for management of recurrent herpes labialis. Expert Opin. Pharmacother. 11, 853-860. doi: 10.1517/ 14656561003691847

van Diemen, F. R., Kruse, E. M., Hooykaas, M. J. G., Bruggeling, C. E., Schürch, A. C., van Ham, P. M., et al. (2016). CRISPR/Cas9-mediated genome editing of herpesviruses limits productive and latent infections. PLoS Pathog. 12:e1005701. doi: 10.1371/journal.ppat.1005701

van Diemen, F. R., and Lebbink, R. J. (2017). CRISPR/Cas9, a powerful tool to target human herpesviruses. Cell Microbiol. 19, 1-9. doi: 10.1111/cmi.12694

Venturi, C. R., Danielli, L. J., Klein, F., Apel, M. A., Montanha, J. A., Bordignon, S. A. L., et al. (2015). Chemical analysis and in vitro antiviral and antifungal activities of essential oils from Glechon spathulata and Glechon marifolia. Pharm. Biol. 53, 682-688. doi: 10.3109/13880209.2014.936944

Vere Hodge, R. A., and Field, H. J. (2013). “Antiviral agents for herpes simplex virus," in Advances in Pharmacology, 1st Edn, Vol. 67, eds J. T. August,
M. W. Anders, F. Murad, and J. T. Coye, (Amsterdam: Elsevier Inc), 1-38. doi: 10.1016/b978-0-12-405880-4.00001-9

Wagstaff, A. J., and Bryson, H. M. (1994). Foscarnet - a reappraisal of its antiviral activity, pharmacokinetic properties and therapeutic use in immunocompromised patients with viral-infections. Drugs 48, 199-226. doi: 10.2165/00003495-199448020-00007

Wald, A., Corey, L., Timmler, B., Magaret, A., Warren, T., Tyring, S., et al. (2014). Helicase-primase inhibitor pritelivir for HSV-2 infection. N. Engl. J. Med. 370, 201-210. doi: 10.1056/NEJMoa1301150

Whitley, R., Davis, E. A., and Suppapanya, N. (2007). Incidence of neonatal herpes simplex virus infections in a managed-care population. Sex Transm. Dis. 34, 704-708. doi: 10.1097/01.olq.0000258432.33412.e2

WHO (2000). General Guidelines for Methodologies on Research and Evaluation of Traditional Medicine World Health Organization. Geneva: World Heal Organisation.

WHO, (2004). WHO Guidelines on Safety Monitoring of Herbal Medicines in Pharmacovigilance Systems. Geneva: World Health Organisation, 82.

Wilhelmus, K. R. (2015). Antiviral treatment and other therapeutic interventions for herpes simplex virus epithelial keratitis. Cochrane Database Syst. Rev. 2015, $1-231$.

Wolf, K. J. (2017). Safety and effectiveness of health care antiseptics; topical antimicrobial drug products for over-the-counter human use final rule. Fed. Regist. 82, 60474-60503.

Woo, S. B., and Challacombe, S. J. (2007). Management of recurrent oral herpes simplex infections. Oral. Surg. Oral. Med. Oral. Pathol. Oral. Radiol. Endod. 103(Suppl. 12), e1-e18.

Wyles, D. L., Patel, A., Madinger, N., Bessesen, M., Krause, P. R., and Weinberg A. (2005). Development of herpes simplex virus disease in patients who are receiving cidofovir. Clin. Infect. Dis. 41, 676-680. doi: 10.1086/432477

Xu, F., Markowitz, L. E., Gottlieb, S. L., and Berman, S. M. (2007). Seroprevalence of herpes simplex virus types 1 and 2 in pregnant women in the United States. Am. J. Obs. Gynecol. 196, e1-e6.

Yuan, H., Ma, Q., Ye, L., and Piao, G. (2016). The traditional medicine and modern medicine from natural products. Molecules 21:E559. doi: 10.3390/ molecules21050559

Zandi, K., Fouladvand, M., Pakdel, P., and Sartavi, K. (2007). Evaluation of in vitro antiviral activity of a brown alga (Cystoseira myrica) from the Persian Gulf against herpes simplex virus type 1. Afr. J. Biotechnol. 6, 2511-2514. doi: 10.5897/ajb2007.000-2399

Ziyaeyan, M., Alborzi, A., Japoni, A., Kadivar, M., Davarpanah, M. A., Pourabbas, B., et al. (2007). Frequency of acyclovir-resistant herpes simplex viruses isolated from the general immunocompetent population and patients with acquired immunodeficiency syndrome. Int. J. Dermatol. 46, 1263-1266. doi: 10.1111/j. 1365-4632.2007.03449.x

Conflict of Interest: The authors declare that the research was conducted in the absence of any commercial or financial relationships that could be construed as a potential conflict of interest.

Copyright (c) 2020 Álvarez, Castillo, Duarte, Arriagada, Corrales, Farías, Henríquez, Agurto-Muñoz and González. This is an open-access article distributed under the terms of the Creative Commons Attribution License (CC BY). The use, distribution or reproduction in other forums is permitted, provided the original author(s) and the copyright owner(s) are credited and that the original publication in this journal is cited, in accordance with accepted academic practice. No use, distribution or reproduction is permitted which does not comply with these terms. 